\title{
Concrete Property and Radionuclide Migration Tests
}

\author{
DM Wellman KE Parker \\ SV Mattigod LN Clayton \\ L Powers MI Wood
}

September 2007

\section{Pacific Northwest}




\title{
DISCLAIMER
}

This report was prepared as an account of work sponsored by an agency of the United States Government. Neither the United States Government nor any agency thereof, nor Battelle Memorial Institute, nor any of their employees, makes any warranty, express or implied, or assumes any legal liability or responsibility for the accuracy, completeness, or usefulness of any information, apparatus, product, or process disclosed, or represents that its use would not infringe privately owned rights. Reference herein to any specific commercial product, process, or service by trade name, trademark, manufacturer, or otherwise does not necessarily constitute or imply its endorsement, recommendation, or favoring by the United States Government or any agency thereof, or Battelle Memorial Institute. The views and opinions of authors expressed herein do not necessarily state or reflect those of the United States Government or any agency thereof.

\author{
PACIFIC NORTHWEST NATIONAL LABORATORY \\ operated by \\ BATTELLE \\ for the \\ UNITED STATES DEPARTMENT OF ENERGY \\ under Contract DE-AC05-76RL01830
}

Printed in the United States of America
Available to DOE and DOE contractors from the
Office of Scientific and Technical Information,
P.O. Box 62, Oak Ridge, TN 37831-0062;
ph: (865) 576-8401
fax: (865) 576-5728
email: reports@adonis.osti.gov

\begin{abstract}
Available to the public from the National Technical Information Service, U.S. Department of Commerce, 5285 Port Royal Rd., Springfield, VA 22161 ph: (800) 553-6847 fax: (703) 605-6900

email: orders@ntis.fedworld.gov

online ordering: http://www.ntis.gov/ordering.htm
\end{abstract}

This document was printed on recycled paper. 


\section{Concrete Property and Radionuclide Migration Tests}

D. M. Wellman

S.V. Mattigod

L. Powers

K.E. Parker

L.N. Clayton

M. I. Wood

September 2007

Prepared for the U.S. Department of Energy

under Contract DE-AC05-76RL01830 


\section{Summary}

Assessing long-term performance of Category 3 waste cement grouts for radionuclide encasement requires knowledge of the radionuclide-cement interactions and mechanisms of retention (i.e., sorption or precipitation). This understanding will enable accurate prediction of radionuclide fate when the waste forms come in contact with groundwater. A set of experiments was initiated during Fiscal Year (FY) 2006 to study the diffusion of rhenium (Re) and iodine (I) from spiked soil into concrete. These half-cells experiments were conducted with concrete half cells that were prepared with and without metallic iron and carbonation and the soil half-cells poised at moisture contents of $4 \%, 7 \%$, and $15 \%$ by mass. Initial concentrations of I and Re were approximately the same in all experiments (between $12.5 \mathrm{and} 15 \mathrm{mg} / \mathrm{g}$ of soil). The data showed that the greatest concentration of I and Re were measured within the first $10 \mathrm{~mm}$ of the concrete monolith $(\sim 10-20 \mathrm{mg} / \mathrm{g})$ with a gradual decrease in concentrations of both elements over the remaining 20 to $30 \mathrm{~mm}$ of concrete monolith. Higher moisture contents and carbonation enabled greater depths of diffusion into the concrete monoliths. At $4 \%$ moisture content, the behavior of I and Re were markedly different. The concentration of I was 40 to $60 \mathrm{mg} / \mathrm{g}$ within the first $5 \mathrm{~mm}$ of the concrete half-cell in contact with sediment, whereas the diffusion of Re was limited to $<5 \mathrm{mg} / \mathrm{g}$ within the same depth of concrete. Such disparity in diffusivity of I and Re into concrete from spiked low-moisture content (4\%) soil half cell suggested potential vapor-phase diffusion of I. Vaporization of I from relatively dry soil (4\% moisture content) in the half cell was confirmed by extracting I-stained polyvinyl chloride sections of the soil half cell with isopropanol. These extracts contained 250 to $800 \mathrm{ppb}$ I, but no Re was detected.

Dynamic leach tests (American National Standards Institute ANSI-16.1) were conducted on a set of $\mathrm{Re} / \mathrm{I}$ and technetium (Tc)/I spiked concrete specimens containing $4 \%, 8 \%$, and $12 \%$ by mass -40 to +60 mesh iron powder or reactive nanoscale zero valent iron particles (RNIP) (Toda America, Inc., Schaumburg, IL). The objective of these tests was to examine whether these iron additives would influence leaching of redox-sensitive contaminant species. The results indicate that inclusion of RNIP relative to metallic iron particles significantly increases the leachability of Re and I from waste-form specimens. The leaching behavior of I and Re in the presence of RNIP was at a significantly increased rate throughout the duration of the test. The leaching indices indicate that in the presence of $4 \%$ and $8 \%$ zero valent iron (ZVI), Tc had higher leachability than Re. However, there was no difference in leachability of Tc and Re when the waste form contained 12\% ZVI. The RNIP formulation consists of elemental iron, magnetite, water, and a water-soluble polymer to maintain a stabilized iron slurry. It is hypothesized that the polymer may form a surface coating on the iron particles that reduces their reactivity and may inhibit reaction with redox-sensitive contaminants within the concrete waste forms.

A set of concrete-soil half cell diffusion experiments was initiated during FY2007 to measure I and Re diffusion from fractured concrete into uncontaminated soil. These half cells were prepared with and without metallic iron, and half of these were carbonated using carbonate solution. These tests were set up under unsaturated conditions ( $4 \%, 7 \%$, and $15 \%$ by wt moisture content). These experiments are in progress and sampling of these half cells will be conducted during FY2008.

It is known that carbonation and microcracking of weathering concrete waste forms affects the leachability and diffusivity of contaminant species. To study the rate of carbonation and concomitant microcrack development, a set of experiments was conducted that consisted of aging concrete specimens encased in Hanford sediments (4\%, 7\%, and $15 \%$ moisture content by weight) in a sealed chamber. The 
specimens were aged for periods of time ranging from 6 months to 2 years. After aging for 6 months, the concrete specimens showed minimal carbonation and no detectable microcracking. The concrete specimens removed after one year of aging showed carbonation only in the surface region of each specimen. The maximum depth of carbonation was approximately $1.5 \mathrm{~mm}$ in the concrete specimen that was encased in soil with $15 \%$ moisture content. Microcracks and adhesion cracks (i.e. cracks along the paste-aggregate contacts within the concrete matrix) were observed relatively frequently in the concrete specimen encased in $15 \%$ moisture content sediment. However, both concrete specimens in contact with sediments at $4 \%$ and $7 \%$ moisture content contained mainly adhesion cracks, and this type of cracking was relatively more common in the specimen in contact with $7 \%$ content. A final set of aged samples will be characterized during FY2008.

A study was initiated during FY2004 to better understand the reactivity of limited solubility uranium(VI) bearing compounds in Portland cement grout specimens. The U(VI) nitrate-spiked specimens were aged for various time spans ranging from 2 weeks to 1 year. The uranium phases in these specimens were identified to be soddyite, becquerelite, uranophane, and autunite. Reliable thermochemical data are not available for these phases under conditions present in concrete waste forms. Therefore to gather such data, synthetic routes were developed for the precipitation of pure uranium phases. In FY2007, the solubility measurements of these U-solid phases were completed under concrete porewater conditions. During FY2008, these data will be analyzed to generate improved input for performance assessment modeling of uranium releases from waste form concrete. 


\section{Acknowledgments}

We thank S.R. Baum, and E.T. Clayton in conducting ICP-OES and ICP-MS analyses, respectively. In addition, the support of Wiss, Janney, Elstner Associates, Inc. for conducting petrographic and scanning electron microscopy analyses is greatly appreciated. 



\section{Contents}

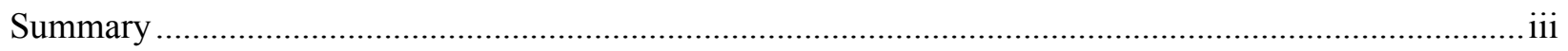

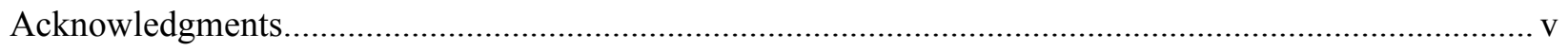

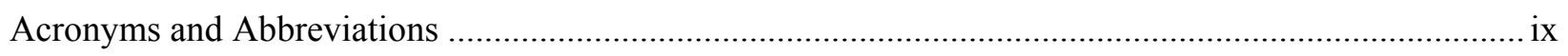

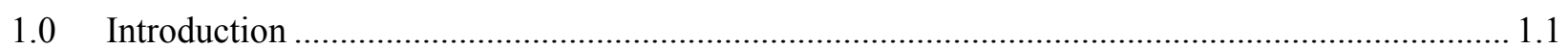

2.0 Determine the Rate of Concrete Carbonation under Simulated Vadose-Zone Conditions at

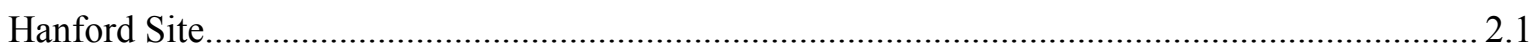

3.0 Concrete-Soil Half-Cell Experiments to Determine the Diffusion of Iodine and Rhenium into

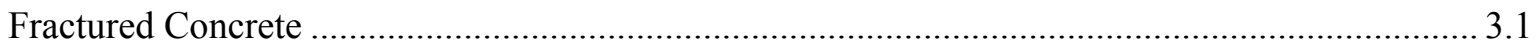

3.1 Specified Concrete Composition for Encasement ............................................................ 3.1

3.2 Materials and Laboratory-Scale Mixture Design ............................................................. 3.1

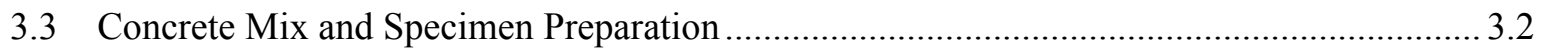

4.0 Concrete-Soil Half-Cell Experiments to Determine the Diffusion of Iodine and Rhenium into

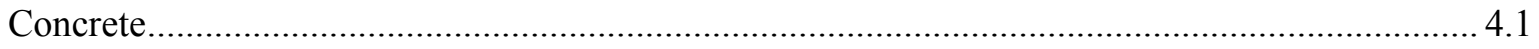

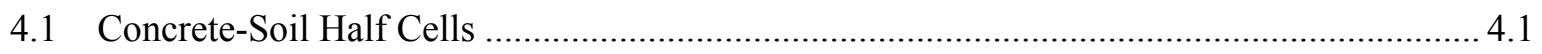

4.2 Concentration Profile Results and Discussion .............................................................. 4.3

5.0 Effect of Iron on the Release of Rhenium, Iodine, and Technetium from Concrete ..................... 5.1

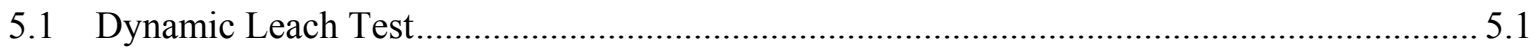

5.2 Effective Diffusivity Calculations ............................................................................ 5.1

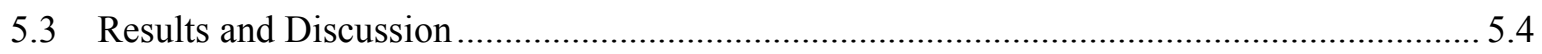

6.0 Reactivity of Limited Solubility U(VI) bearing Compounds in Concrete .................................... 6.1

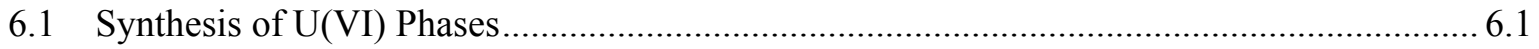

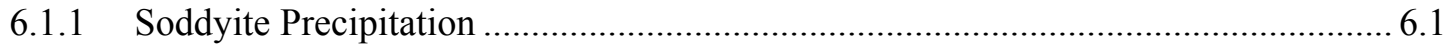

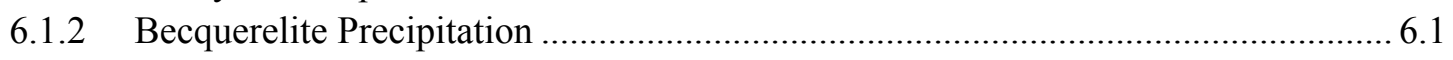

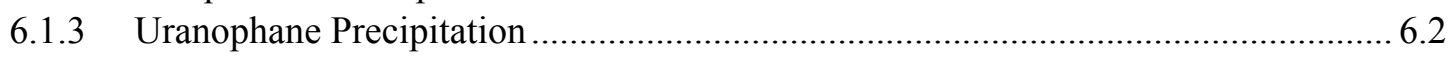

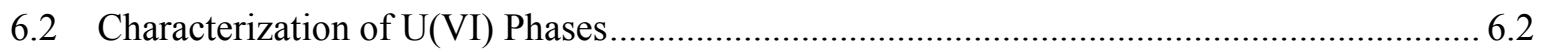

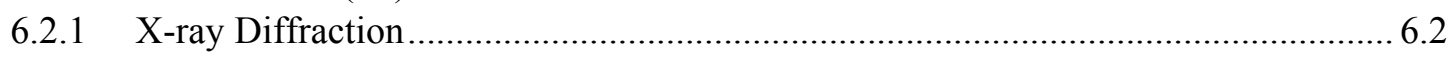

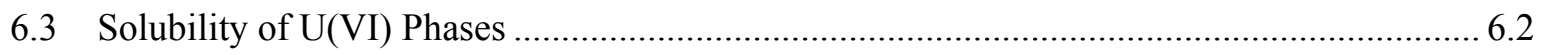

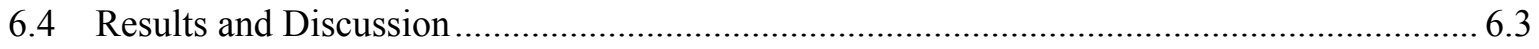

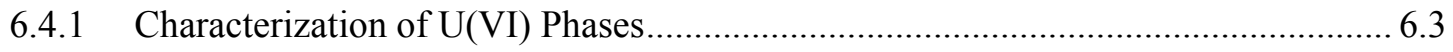

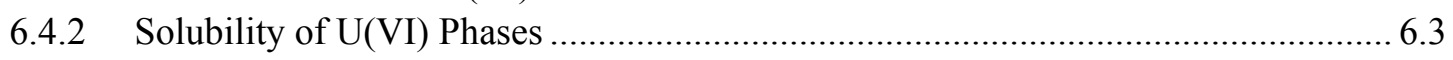

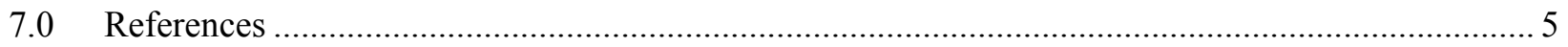




\section{Figures}

Figure 4.1. a) Mechanism for Soil Sampling from a Concrete-Soil Diffusion Half Cell. b) Soil

Sampling from a Diffusion Half Cell

Figure 4.2. Concentration Profiles for Soil Half-Cell I and Re Profiles at 4\%, 7\%, and 15\% Moisture

Content by Weight in a) Iron, Carbonated, b) Iron, Not Carbonated, c) No Iron, Carbonated, and

d) No Iron, not Carbonated Concrete Monoliths.

Figure 4.3. Concentration Profiles for Concrete Half-Cell I and Re Profiles at 4\% Moisture Content by Weight in a) Iron, Carbonated, b) Iron, Not Carbonated, c) No Iron, Carbonated, and d) No Iron, Not Carbonated Concrete Monoliths

Figure 4.4. Concentration Profiles for Concrete Half-Cell I and Re Profiles at 7\%, and 15\% Moisture Content by Weight in a) Iron, Carbonated, b) Iron, Not Carbonated, c) No Iron, Carbonated, and

d) No Iron, Not Carbonated Concrete Monoliths.

Figure 5.1. Dynamic Leach Test: Cumulative Leaching Fraction as a Function of Time for I, Re, and Tc

Figure 6.1. X-ray Diffraction Pattern for Soddyite (top), Becquerelite (middle), and Uranophane (bottom)

\section{Tables}

Table 3.1. Material Specifications and Composition

Table 3.2. Laboratory-scale Material Specification and Composition................................................... 3.2

Table 3.3. Characteristics of Cement Specimens Used in Fractured Concrete-Soil Half-Cell Tests........ 3.3

Table 4.1. Characteristics of Concrete Specimens Used in Concrete-Soil Half Cells ............................ 4.2

Table 4.2. Characteristics of the Concrete-Soil Half Cells .................................................................... 4.2

Table 5.1. Characteristics of Cement Specimens Used in ANSI Dynamic Leach Tests ........................ 5.1

Table 5.2. Composition of Typical Hanford Groundwater .................................................................. 5.2

Table 5.3. Leach Index Data for Re and I as a Functions of Metallic Iron-Particle Concentration.......... 5.5

Table 5.4. Leach Index Data for Tc and I as a Functions of ZVI Particle Concentration....................... 5.6

Table 6.1. Chemical Composition of Portland Cement-Equilibrated Waters .......................................... 6.2 


\section{Acronyms and Abbreviations}

$\begin{array}{ll}\text { ANSI } & \text { American National Standards Institute } \\ \text { BFS } & \text { blast furnace slag } \\ \text { FY } & \text { Fiscal Year } \\ \text { I } & \text { iodine } \\ \text { ICP-MS } & \text { inductively coupled plasma-mass spectrometry } \\ \text { ICP-OES } & \text { inductively coupled plasma-optical emission spectrometry } \\ \text { L } & \text { limestone } \\ \text { OPC } & \text { ordinary Portland cement } \\ \text { PVC } & \text { polyvinyl chloride } \\ \text { Re } & \text { rhenium } \\ \text { RNIP } & \text { reactive nanoscale zero valent iron particles } \\ \text { SRPC } & \text { sulfate-resistant Portland cement } \\ \text { Tc } & \text { technetium } \\ \text { U(VI) } & \text { Uranium (VI) } \\ \text { ZVI } & \text { zero valent iron }\end{array}$




\subsection{Introduction}

One of the methods being considered for safely disposing of Category 3 low-level radioactive wastes is to encase the waste in concrete. Such concrete encasement would contain and isolate the waste packages from the hydrologic environment and would act as an intrusion barrier. The current plan for waste isolation consists of stacking low-level waste packages on a trench floor, surrounding the stacks with reinforced steel, and encasing these packages with concrete. These concrete-encased waste stacks are expected to vary in size with maximum dimensions of $6.4 \mathrm{~m}$ long, $2.7 \mathrm{~m}$ wide, and $4 \mathrm{~m}$ high. The waste stacks are expected to have a surrounding minimum thickness of $15 \mathrm{~cm}$ of concrete encasement. These concrete-encased waste packages are expected to withstand environmental exposure (solar radiation, temperature variations, and precipitation) until an interim soil cover or permanent closure cover is installed, and remain largely intact thereafter.

Any failure of concrete encasement may result in water intrusion and consequent mobilization of radionuclides from the waste packages. The mobilized radionuclides may escape from the encased concrete by mass flow and/or diffusion and move into the surrounding subsurface environment. Therefore, it is necessary to conduct an assessment of the performance of the concrete encasement structure and the ability of the surrounding soil to retard radionuclide migration. The retardation factors for radionuclides contained in the waste packages can be determined from measurements of diffusion coefficients for these contaminants through concrete and fill material.

The radionuclides ${ }^{129} \mathrm{I},{ }^{75} \mathrm{Se},{ }^{99} \mathrm{Tc}$, and ${ }^{238} \mathrm{U}$ are identified as long-term dose contributors in Category 3 waste (Mann et al. 2001; Wood et al. 1995). Because of their anionic nature in aqueous solutions, ${ }^{129} \mathrm{I}$, ${ }^{75} \mathrm{Se},{ }^{99} \mathrm{Tc}$, and carbonate-complexed ${ }^{238} \mathrm{U}$ may readily leach into the subsurface environment (Serne et al. 1993, 1992, 1989, and 1995). The leachability and/or diffusion of radionuclide species must be measured in order to assess the long-term performance of waste grouts when contacted with vadose-zone porewater or groundwater. Such data can be obtained by subjecting waste concrete specimens to standardized leach tests.

The objective of this investigation was to quantify the diffusion of iodine (I) and rhenium (Re), which was used as an analog for technetium (Tc), within concrete-soil half-cell experiments. A set of diffusion experiments using carbonated concrete-soil half cells were conducted under unsaturated conditions (4\% and $7 \%$ moisture content by weight). Concrete half-cell specimens were prepared with and without colloidal metallic iron addition and were carbonated using supercritical carbon dioxide. Spikes of I and Re were added to the sediment half cell to achieve measurable diffusion profile in the concrete part of the half cell. From the concentration data, concentration profiles were constructed. In addition, properties of concrete materials likely to influence radionuclide migration, such as carbonation, were evaluated in an effort to correlate these properties with the diffusion of I and Re. 


\subsection{Determine the Rate of Concrete Carbonation under Simulated Vadose-Zone Conditions at Hanford Site}

A number of cement specimens were prepared and encased in soil samples from the Hanford Site during Fiscal Year (FY) 2005. Samples are being tested at three different soil moisture contents (4\%, 7\%, and $15 \%$ by mass) that reflect the vadose-zone conditions at Hanford. The soil-encased cement specimens were sealed to prevent moisture loss and aged for various time periods ranging from 6 months to 3 years. At the end of each aging period, three encased cement specimens (one from each moisture content) are removed and analyzed to determine the depth of carbonation. Microscopic analyses are being conducted to assess the rate of expected microcracking and concomitant increase in the rate of radionuclide diffusion from the low-level waste and mixed low-level waste concrete.

During FY2006, the first set of concrete monoliths (aged 6 months) were removed and analyzed for carbonation and microcracking. Microscopic analyses revealed no indication of microcracking. Moreover, the extent of carbonation was minimal. It was decided the next set of concrete monoliths would be removed for analyses after a period of one year from that time. The results of carbonation, petrographic microscopy, and scanning electron microscopy analyses conducted on these cores are presented in Appendix 1. The final set of monoliths will be removed mid-year FY2008. 


\subsection{Concrete-Soil Half-Cell Experiments to Determine the Diffusion of Iodine and Rhenium into Fractured Concrete}

A set of diffusion experiments was initiated during FY2007 using fractured concrete-soil half cells. These half cells were prepared with and without metallic iron, and half of these were carbonated using carbonate solution. These tests were set up under unsaturated conditions $(4 \%, 7 \%$, and $15 \%$ moisture content by weight). Soil half-cell specimens were spiked with I and Re to achieve a measurable diffusion profile in the concrete part of the half cell. Experimental conditions in these tests are similar to the concrete-soil and soil-soil half-cell experiments conducted previously (FY 1998-2005). In FY2008, the soil and concrete half cells will be sectioned to measure the concentration of I and Re using inductively coupled plasma-mass spectrometry (ICP-MS) and inductively coupled plasma-optical emission spectrometry (ICP-OES), respectively, in soil and concrete thin slices. From the concentration data, probit plots will be constructed and the diffusion coefficients for these contaminants determined. Details regarding the preparation of the concrete-soil half cells are presented below.

\subsection{Specified Concrete Composition for Encasement}

The concrete composition for the burial encasement was specified in Specification for Concrete Encasement for Contact-Handled Category 3 Waste. ${ }^{\text {(a) }}$ This specification was used as the basis to prepare a concrete for fabrication of test specimens. The specified composition includes sulfate-resistant Portland Type I or Type II cement, a pozzolanic material (Class F fly ash), fine and coarse aggregates, and steel fiber. Additional specifications include a water-to-cement ratio of 0.4 and an air content $6.0 \pm 1.5 \%$. The nominal proportions and material specifications based on this initial design are listed in Table 3-1.

Table 3-1. Material Specifications and Composition

\begin{tabular}{||l|l|l|c||}
\hline \multicolumn{1}{||}{ Material } & \multicolumn{1}{|c|}{ Specifications } & \multicolumn{1}{c|}{$\begin{array}{c}\text { Specified Field } \\
\text { Mix }\end{array}$} & $\begin{array}{c}\text { Sormalized } \\
\text { Specification } \\
\text { Design }\end{array}$ \\
\hline \hline Cement & Portland Type I or Type I/II sulfate-resistant cement & $381 \mathrm{~kg} / \mathrm{m}^{3}$ & 0.27 \\
\hline Fly Ash & Class F fly ash; nominal 15\% of cement by volume & $54 \mathrm{~kg} / \mathrm{m}^{3}$ & 0.04 \\
\hline Coarse Aggregate & No. 676 or equivalent (3/4" nominal size) & $55 \%$ by volume & 0.04 \\
\hline Fine Aggregate & Sand & $45 \%$ by volume & 0.51 \\
\hline Water & Nominal water:cement ratio: 0.4 & $399 \mathrm{~kg} / \mathrm{m}^{3}$ & 0.10 \\
\hline Steel Fiber & Deformed Type I, nominal length $2.5-3.8 \mathrm{~cm}\left(1-1.5^{\prime \prime}\right)$ & $59 \mathrm{~kg} / \mathrm{m}^{3}$ & 0.04 \\
\hline Air Content & & $6.0 \pm 1.5 \%$ & \\
\hline \hline
\end{tabular}

\subsection{Materials and Laboratory-Scale Mixture Design}

A laboratory-scale concrete mixture (Table 3-2) was prepared based on specifications shown in Table 3-1. Because of the required small dimensions of laboratory test specimens, the size of the coarse aggregate and the dimensions of the steel fiber specified in Table 3-1 were proportionately reduced. This was accomplished by decreasing the $2-\mathrm{cm}(\sim 0.75 \mathrm{in}$.) coarse aggregate size in the original specification to a particle size ranging from $2.83 \mathrm{~mm}$ to $2 \mathrm{~mm}$ in the laboratory mix. Aggregate passing a 7-mesh sieve and retained on a 10-mesh sieve met this particle size specification. The scaled-down steel fibers used in the laboratory mix consisted of iron particles. Based on these modifications, a concrete mix was prepared 
that consisted of Portland Cement (Type I and II, American Society for Testing and Materials C-150 compliant), Class F fly ash, scaled-down coarse aggregate, fine aggregate, iron particles, and a waterentraining agent (Polyheed 997). The water-entraining agent was included in the mix to facilitate the workability of the concrete. The volumes of the Polyheed 997 and the air-entraining agent, MB AE 90, were not included in the normalization calculations because of their negligible contribution to the overall mix volume. The material specification and composition for the laboratory-scale concrete mixture is given in Table 3-2.

Table 3-2. Laboratory-scale Material Specification and Composition

\begin{tabular}{||c|c|c|c||}
\hline Material & $\begin{array}{c}\text { Material Specifications for } \\
\text { Field Mix }\end{array}$ & $\begin{array}{c}\text { Normalized } \\
\text { Laboratory Design }\end{array}$ & $\begin{array}{c}\text { Material Specifications Used in } \\
\text { Revised Laboratory Mix } \\
\text { Comparison }\end{array}$ \\
\hline \hline Cement & $\begin{array}{c}\text { Portland Type I or Type I/II } \\
\text { sulfate-resistant cement }\end{array}$ & 0.27 & Portland Type I \& II \\
\hline Fly Ash & $\begin{array}{c}\text { Class F fly ash; nominal 15\% of } \\
\text { cement by volume }\end{array}$ & 0.04 & $\begin{array}{c}\text { Class F fly ash; nominal 20\% of } \\
\text { cement by volume }\end{array}$ \\
\hline $\begin{array}{c}\text { Coarse } \\
\text { Aggregate }\end{array}$ & $\begin{array}{c}\text { No. 676 or equivalent } \\
\text { (3/4” nominal size) }\end{array}$ & 0.04 & $\begin{array}{c}\text { Sieve size }+7 \text { to }-10 \\
(2.83-2 \text { mm size })\end{array}$ \\
\hline Fine Aggregate & Sand & 0.51 & Sand -10 sieve size $(<2 \mathrm{~mm})$ \\
\hline Water & Nominal water:cement ratio: 0.4 & 0.10 & Water-to-cement ratio: 0.5 \\
\hline Iron Powder & Iron particles & 0.04 & -200 mesh \\
\hline Polyheed 997 & & 0.00375 & Water-entraining agent \\
\hline Air Content & $6.0 \pm 1.5 \%$ & $6.0 \pm 1.5 \%$ & -- \\
\hline \hline
\end{tabular}

\subsection{Concrete Mix and Specimen Preparation}

Concrete monoliths were prepared with mix components added in the order: water, steel (if applicable), coarse aggregate, fine aggregate, fly ash, cement, Polyheed 997, and MB AE 90. The concrete was mixed on medium speed using a Hobart three-speed, bench-top mixer in a $4 \mathrm{~L}$ steel bowl. The concrete molds for casting specimens were fabricated from Schedule 40 polyvinyl chloride (PVC) piping material. Gaskets were glued to the bottom of the molds and leak tested before use. The PVC forms were pre-treated with form release, a liquid that allows the concrete specimen to release easily from the mold. The first treatment was applied 3 days prior, and the second treatment was applied a few hours before wet concrete was added to the molds. The PVC molds were filled in the vertical position. After filling, the molds were lightly tapped on the laboratory bench until a significant decrease in the release of air bubbles was observed. The forms were stored in a humidity chamber for 28 days to provide moisture while the concrete set. The concrete monoliths were subsequently removed from the molds and half of the monoliths were carbonated by soaking the cores for 7 days in a saturated sodium-bicarbonate solution. The characteristics of the specimens used are listed in Table 3-3. In order to fracture the core, but prevent the formation of rubble, the cores where shrink wrapped and struck with a hammer.

The diffusion tests are being conducted under unsaturated conditions at $4 \%, 7 \%$, and $15 \%$ (moisture content by weight). One concrete core of each composition was encased in a Schedule 40, $24 \mathrm{~cm}$ long, PVC pipe. The volume of each pipe was filled with Hanford Site sediment at the respective moisture content that was spiked with I and Re to attain a measurable diffusion profile into the fractured concrete. The ends of each pipe were machined and fit with o-ring gaskets to ensure the test cells were sealed. The 
diffusion tests were allowed to set horizontally and undisturbed for a period of 1 year with periodic rotation of the cell by 90 degrees.

Table 3-3. Characteristics of Cement Specimens Used in Fractured Concrete-Soil Half-Cell Tests

\begin{tabular}{|c|c|c|c|c|c|c|c|c|c|}
\hline \multirow{2}{*}{$\begin{array}{l}\text { Specimen } \\
\text { No. }\end{array}$} & \multirow{2}{*}{$\begin{array}{l}\text { Length } \\
(\mathrm{cm})\end{array}$} & \multirow{2}{*}{$\begin{array}{l}\text { Diameter } \\
(\mathrm{cm})\end{array}$} & \multirow{2}{*}{$\begin{array}{c}\text { Surface Area } \\
\left(\mathrm{cm}^{2}\right)\end{array}$} & \multirow{2}{*}{$\begin{array}{l}\text { Volume } \\
\left(\mathrm{cm}^{3}\right)\end{array}$} & \multicolumn{3}{|c|}{$\begin{array}{l}\text { Moisture } \\
\text { Content }\end{array}$} & \multicolumn{2}{|c|}{ Treatment } \\
\hline & & & & & $4 \%$ & $8 \%$ & $12 \%$ & Iron & Carbonation \\
\hline 1 & 4.15 & 4.33 & 85.89 & 61.10 & $\mathrm{x}$ & & & No & No \\
\hline 2 & 3.89 & 4.34 & 82.44 & 57.35 & $\mathrm{x}$ & & & Yes & No \\
\hline 3 & 4.15 & 4.33 & 86.04 & 61.25 & $\mathrm{x}$ & & & No & Yes \\
\hline 4 & 4.02 & 4.33 & 84.04 & 59.10 & $\mathrm{x}$ & & & Yes & Yes \\
\hline 5 & 4.24 & 4.33 & 87.02 & 62.32 & & $\mathrm{x}$ & & No & No \\
\hline 6 & 3.98 & 4.34 & 83.75 & 58.77 & & $\mathrm{x}$ & & Yes & No \\
\hline 7 & 4.18 & 4.34 & 86.63 & 61.89 & & $\mathrm{x}$ & & No & Yes \\
\hline 8 & 4.12 & 4.34 & 85.68 & 60.87 & & $\mathrm{x}$ & & Yes & Yes \\
\hline 9 & 4.37 & 4.34 & 89.05 & 64.51 & & & $\mathrm{x}$ & No & No \\
\hline 10 & 3.95 & 4.34 & 83.31 & 58.29 & & & $\mathrm{x}$ & Yes & No \\
\hline 11 & 4.76 & 4.34 & 94.54 & 70.48 & & & $\mathrm{x}$ & No & Yes \\
\hline 12 & 4.52 & 4.34 & 91.26 & 66.91 & & & $\mathrm{x}$ & Yes & Yes \\
\hline
\end{tabular}




\subsection{Concrete-Soil Half-Cell Experiments to Determine the Diffusion of Iodine and Rhenium into Concrete}

A set of diffusion experiments was initiated during FY2006 using concrete-soil half cells. These halfcells were prepared with and without metallic iron, and half of these were carbonated using carbonate solution. These tests were set up under unsaturated conditions $(4 \%, 7 \%$, and $15 \%$ moisture content by weight). Soil half-cell specimens were spiked with I and Re to achieve a measurable diffusion profile into the concrete part of the half cell. Experimental conditions in these tests were similar to the successful concrete-soil and soil-soil half-cell experiments conducted previously (FY 1998-2005) that measured contaminant migration from concrete to soil and soil to soil.. In FY2007, the soil and concrete half cells were sectioned to measure the concentration of I and Re using ICP-MS and ICP-OES, respectively, in soil and concrete thin slices. In FY2008, probit plots will be constructed from the concentration data and the diffusion coefficients for these contaminants will be determined. We will also correlate the calculated diffusion coefficients with the degree of microcracking in the cement specimens used in the half-cell experiments. For this purpose, we will microscopically analyze thin slices of the concrete specimens from the half cells and try to quantify the degree of microcracking induced by carbonation via scanning electron microscopy. The porosity of the concrete will be measured via mercury porosimetry.

\subsection{Concrete-Soil Half Cells}

Diffusion tests were conducted to assess the effects of concrete carbonation and the inclusion of colloidal iron on the rate of diffusion of key, long-lived, mobile contaminants (I, Re, and Tc), in unsaturated Hanford sediments ( $\sim \%, 7 \%$, and $15 \%$ moisture content by weight) in contact with a spiked concrete monolith. Stable I and Re were added to the water component prior to mixing with the sediment. The experiments were conducted using a half cell of Trench 8 soil $(\sim 4 \mathrm{~cm}$ diameter and $20 \mathrm{~cm}$ long) spiked with $\mathrm{I}$ and $\mathrm{Re}$ in contact with a concrete monolith $(\sim 4 \mathrm{~cm}$ diameter and $\sim 4 \mathrm{~cm} \mathrm{long})$. Trench 8 soil is a medium-coarse sand obtained from the sidewall of trench 8 in the W-5 burial ground located in the 200 West Area on the Hanford Site. The physical, chemical, and mineralogical properties of this soil have been previously characterized by Serne et al. (1993). Concrete monoliths were prepared in two separate batches based on the laboratory-scale specifications for the concrete (Table 3-2): one batch contained iron particles, the other batch did not contain any added iron. Within the two batches of concrete, with iron and without iron, half the monoliths were carbonated using supercritical carbon dioxide. The resulting compositions consisted of four concrete specimens: 1) no iron, carbonated, 2) no iron, not carbonated, 3) iron, carbonated, and 4) iron, not carbonated. The characteristics of the specimens are listed in Table 4-1.

The diffusion tests were conducted under unsaturated conditions at $4 \%, 7 \%$, and $15 \%$ (moisture content by weight). One concrete core of each composition was encased in a Schedule $40,24 \mathrm{~cm}$ long, PVC pipe. The volume of each pipe was filled with Hanford Site sediment at 4\%, 7\%, or 15\% (moisture content by weight), respectively. The ends of each pipe were machined and fit with o-ring gaskets to ensure the test cells were sealed. The diffusion tests were allowed to set horizontally and undisturbed for a period of 1 year with periodic rotation of the cell by 90 degrees. Characteristics of the concrete-soil diffusion half cells are listed in Table 4-2. 
Table 4-1. Characteristics of Concrete Specimens Used in Concrete-Soil Half Cells

\begin{tabular}{||c|c|c|c|c|c|c|c||}
\hline \hline $\begin{array}{c}\text { Specimen } \\
\text { No. }\end{array}$ & $\begin{array}{c}\text { Length } \\
(\mathrm{cm})\end{array}$ & $\begin{array}{c}\text { Diameter } \\
(\mathrm{cm})\end{array}$ & $\begin{array}{c}\text { Surface Area } \\
\left(\mathrm{cm}^{2}\right)\end{array}$ & $\begin{array}{c}\text { Volume } \\
\left(\mathrm{cm}^{3}\right)\end{array}$ & $\begin{array}{c}\text { Density } \\
\left(\mathrm{g} / \mathrm{cm}^{3}\right)\end{array}$ & $\begin{array}{c}\text { Collodial } \\
\text { Iron }\end{array}$ & Carbonated \\
\hline \hline 1 & 4.21 & 4.32 & 86.26 & 61.50 & 2.21 & Yes & Yes \\
\hline 2 & 4.33 & 4.32 & 87.99 & 63.37 & 2.18 & Yes & No \\
\hline 3 & 4.26 & 4.32 & 87.23 & 62.55 & 2.08 & No & Yes \\
\hline 4 & 4.39 & 4.33 & 89.09 & 64.55 & 2.04 & No & No \\
\hline 5 & 4.34 & 4.32 & 88.16 & 63.55 & 2.23 & Yes & Yes \\
\hline 6 & 4.26 & 4.33 & 87.22 & 62.54 & 2.21 & Yes & No \\
\hline 7 & 4.15 & 4.32 & 85.69 & 60.89 & 2.10 & No & Yes \\
\hline 8 & 4.38 & 4.32 & 88.72 & 64.16 & 2.06 & No & No \\
\hline 9 & 4.27 & 4.32 & 87.15 & 62.46 & 2.23 & Yes & Yes \\
\hline 10 & 4.27 & 4.32 & 87.39 & 62.73 & 2.19 & Yes & No \\
\hline 11 & 4.15 & 4.33 & 85.76 & 60.95 & 2.08 & No & Yes \\
\hline 12 & 4.43 & 4.32 & 89.58 & 65.09 & 2.06 & No & No \\
\hline \hline
\end{tabular}

Table 4-2. Characteristics of the Concrete-Soil Half Cells

\begin{tabular}{|c|c|c|c|c|c|c|c|c|c|c|c|}
\hline $\begin{array}{l}\text { Cell } \\
\text { No. }\end{array}$ & $\begin{array}{c}\text { Concrete } \\
\text { Treatment }\end{array}$ & $\begin{array}{l}\text { I Conc. } \\
\text { (g/g soil) }\end{array}$ & $\begin{array}{l}\text { Re Conc. } \\
\text { (g/g soil) }\end{array}$ & $\begin{array}{c}\text { Length } \\
\text { Concrete } \\
\text { Half Cell } \\
(\mathrm{cm}) \\
\end{array}$ & \begin{tabular}{|c|} 
Volume of \\
Concrete \\
Half-Cell \\
$\left(\mathrm{cm}^{3}\right)$
\end{tabular} & $\begin{array}{c}\text { Density } \\
\text { Concrete } \\
\left(\mathrm{g} / \mathrm{cm}^{3}\right)\end{array}$ & $\begin{array}{l}\text { Volume of } \\
\text { Soil Half- } \\
\text { Cell }\left(\mathrm{cm}^{3}\right)\end{array}$ & $\begin{array}{c}\text { Volume } \\
\text { of Half- } \\
\text { Cell }\left(\mathrm{cm}^{3}\right)\end{array}$ & $\begin{array}{c}\text { Density } \\
\text { Soil } \\
\left(\mathrm{g} / \mathrm{cm}^{3}\right)\end{array}$ & $\begin{array}{c}\text { Soil } \\
\text { Moisture } \\
\text { Content } \\
(\%)\end{array}$ & $\begin{array}{c}\text { Test } \\
\text { Duration } \\
\text { (days) }\end{array}$ \\
\hline $\begin{array}{c}\text { CS-I- } \\
4 \%\end{array}$ & $\begin{array}{c}\text { Iron, } \\
\text { Carbonated }\end{array}$ & $1.35 \times 10^{-2}$ & $1.34 \times 10^{-2}$ & 4.21 & 61.50 & 2.21 & 239.260 & 300.76 & 1.58 & 4.0 & 348 \\
\hline \begin{tabular}{||c|} 
CS-II- \\
$4 \%$
\end{tabular} & $\begin{array}{c}\text { Iron, Not } \\
\text { Carbonated }\end{array}$ & $1.35 \times 10^{-2}$ & $1.34 \times 10^{-2}$ & 4.33 & 63.37 & 2.18 & 237.390 & 300.76 & 1.56 & 4.0 & 348 \\
\hline $\begin{array}{c}\text { CS-III- } \\
4 \%\end{array}$ & $\begin{array}{c}\text { No Iron, } \\
\text { Carbonated }\end{array}$ & $1.35 \times 10^{-2}$ & $1.34 \times 10^{-2}$ & 4.26 & 62.55 & 2.08 & 238.209 & 300.76 & 1.58 & 4.0 & 348 \\
\hline \begin{tabular}{|c|} 
CS-IV- \\
$4 \%$ \\
\end{tabular} & $\begin{array}{c}\text { No Iron, Not } \\
\text { Carbonate }\end{array}$ & $1.35 \times 10^{-2}$ & $1.34 \times 10^{-2}$ & 4.39 & 64.55 & 2.04 & 236.206 & 300.76 & 1.56 & 4.0 & 348 \\
\hline \begin{tabular}{|c|} 
CS-I- \\
$7 \%$
\end{tabular} & $\begin{array}{c}\text { Iron, } \\
\text { Carbonated }\end{array}$ & $1.25 \times 10^{-2}$ & $1.25 \times 10^{-2}$ & 4.34 & 63.55 & 2.23 & 237.212 & 300.76 & 1.61 & 7.1 & 354 \\
\hline \begin{tabular}{|c|} 
CS-II- \\
$7 \%$ \\
\end{tabular} & $\begin{array}{c}\text { Iron, Not } \\
\text { Carbonated }\end{array}$ & $1.25 \times 10^{-2}$ & $1.25 \times 10^{-2}$ & 4.26 & 62.54 & 2.21 & 238.220 & 300.76 & 1.62 & 7.1 & 354 \\
\hline \begin{tabular}{|c|} 
CS-III- \\
$7 \%$
\end{tabular} & $\begin{array}{c}\text { No Iron, } \\
\text { Carbonated }\end{array}$ & $1.25 \times 10^{-2}$ & $1.25 \times 10^{-2}$ & 4.15 & 60.89 & 2.10 & 239.876 & 300.76 & 1.53 & 7.1 & 354 \\
\hline \begin{tabular}{|c|} 
CS-IV- \\
$7 \%$ \\
\end{tabular} & $\begin{array}{c}\text { No Iron, Not } \\
\text { Carbonate }\end{array}$ & $1.25 \times 10^{-2}$ & $1.25 \times 10^{-2}$ & 4.38 & 64.16 & 2.06 & 236.599 & 300.76 & 1.56 & 7.1 & 354 \\
\hline \begin{tabular}{|c|} 
CS-I- \\
$15 \%$ \\
\end{tabular} & $\begin{array}{c}\text { Iron, } \\
\text { Carbonated } \\
\end{array}$ & $1.50 \times 10^{-2}$ & $1.50 \times 10^{-2}$ & 4.27 & 62.46 & 2.23 & 238.297 & 300.76 & 1.72 & 15.0 & 355 \\
\hline \begin{tabular}{|c|} 
CS-II- \\
$15 \%$
\end{tabular} & $\begin{array}{c}\text { Iron, Not } \\
\text { Carbonated }\end{array}$ & $1.50 \times 10^{-2}$ & $1.50 \times 10^{-2}$ & 4.27 & 62.73 & 2.19 & 238.035 & 300.76 & 1.70 & 15.0 & 355 \\
\hline $\begin{array}{c}\text { CS-III- } \\
15 \%\end{array}$ & $\begin{array}{c}\text { No Iron, } \\
\text { Carbonated }\end{array}$ & $1.50 \times 10^{-2}$ & $1.50 \times 10^{-2}$ & 4.15 & 60.95 & 2.08 & 239.806 & 300.76 & 1.72 & 15.0 & 355 \\
\hline $\begin{array}{c}\text { CS-IV- } \\
15 \%\end{array}$ & $\begin{array}{l}\text { No Iron, Not } \\
\text { Carbonate }\end{array}$ & $1.50 \times 10^{-2}$ & $1.50 \times 10^{-2}$ & 43 & 9 & .06 & 5 & 6 & 1.70 & 15.0 & 355 \\
\hline
\end{tabular}

At the conclusion of the test period, the end caps of the cells were removed and the sediment was extruded at approximately $1 \mathrm{~cm}$ intervals along the length of the half cell (Figure 4.1). The soil samples were weighed and extracted with deionized water. 


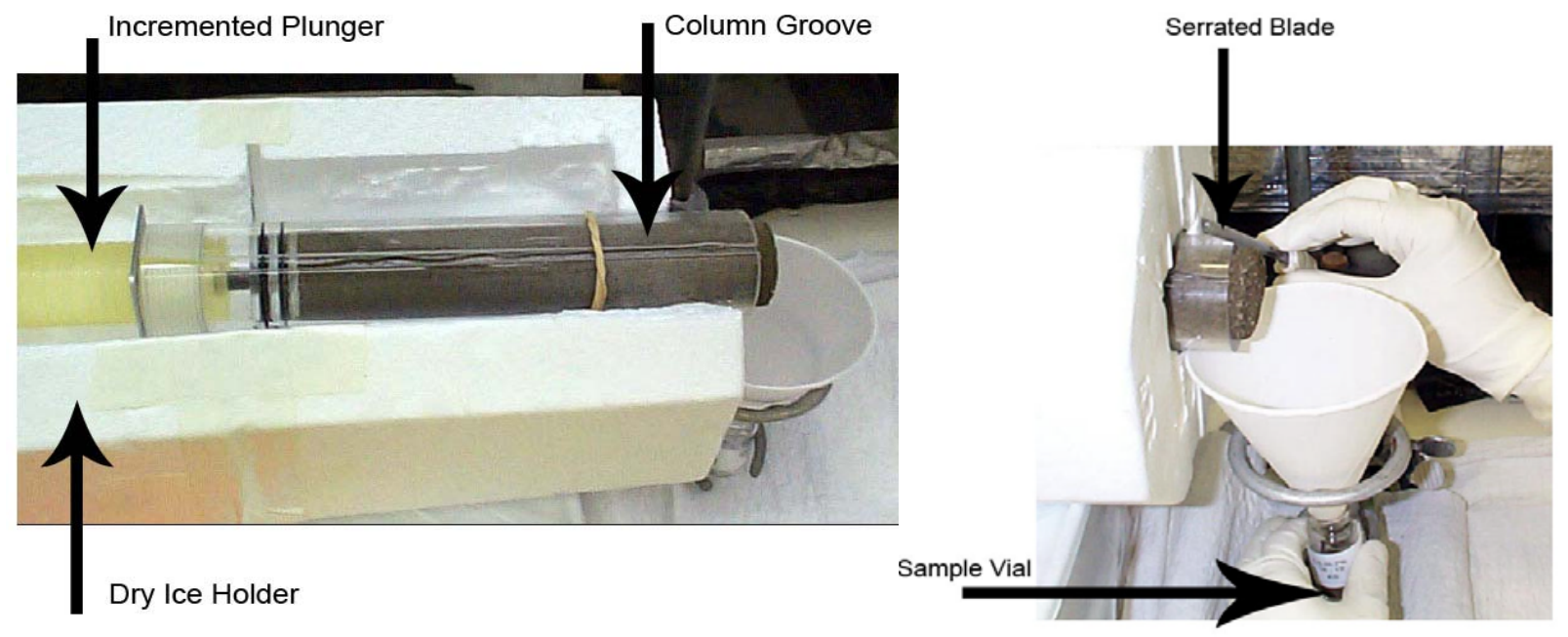

Figure 4.1. a) Mechanism for Soil Sampling from a Concrete-Soil Diffusion Half Cell. b) Soil Sampling from a Diffusion Half Cell.

Concrete half cells were thin-sliced using a Buehler slow-speed saw fitted with a diamond blade. Cutting was done without water cooling to prevent the leaching of soluble I and Re during the cutting process. The concrete slices were then ground using an agate mortar and pestle. One-to-one (by mass) water extracts were done on both sediment and concrete fractions. The concentrations of I and Re were measured via ICP-MS and ICP-OES, respectively.

\subsection{Concentration Profile Results and Discussion}

Figure 4.2 presents graphs depicting the concentration profiles for I and Re within the sediment half from concrete-soil half-cell diffusion experiments. Figure 4.3 presents the mass balance in soil and 


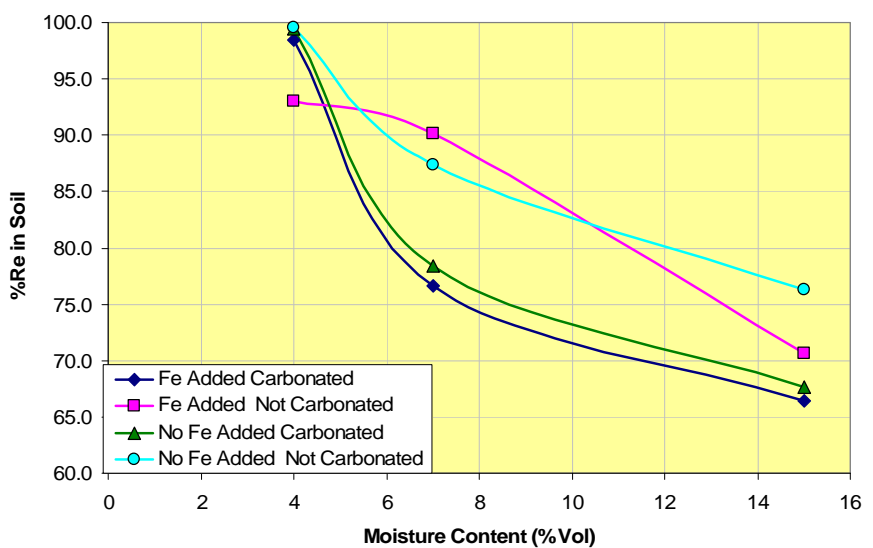

concrete half-cells.

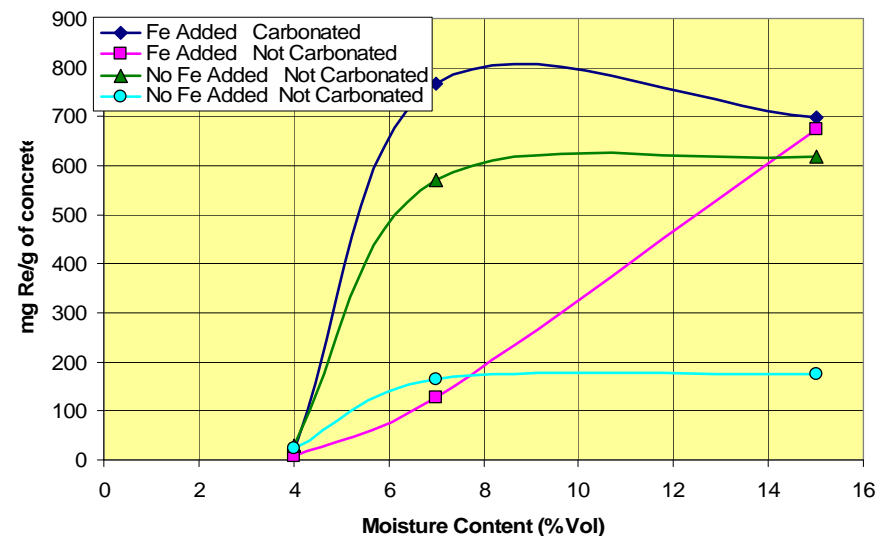



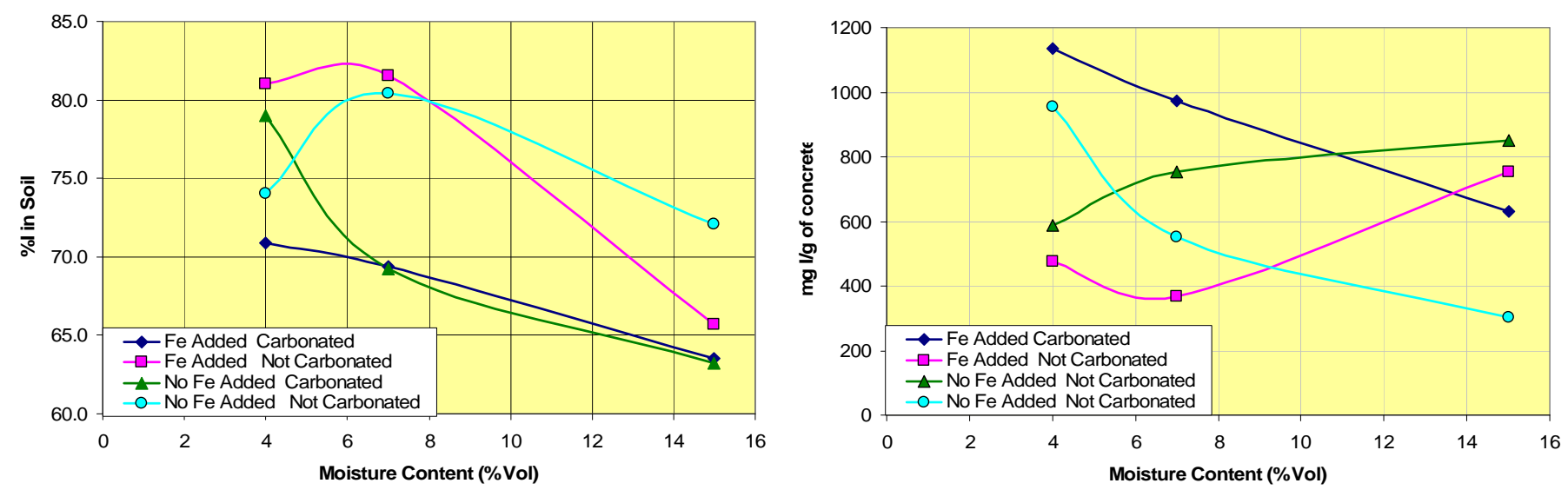

Figure 4.3. Mass Balance for Soil Half-Cell I and Re Profiles at 4\%, 7\%, and 15\% Moisture Content by Weight in a) Fraction of Re Remaining in Soil, b) Measured Mass of Re Diffused into Concrete, c) Fraction of I Remaining in Soi, and d) Measured Mass of I Diffused into Concrete.

Table 4-3 and

Table 4-4 present the concentration profiles for I and Re, respectively, within the sediment half from concrete-soil half-cell diffusion experiments. The overall mass loss in the soil half-cells shows that carbonated concrete half-cells, regardless of Fe content, have the most significant diffusion of I and Re into the concrete half-cell (Figure 4.3). Within analytical error, there is no quantifiable difference in I and Re diffusion from the soil to concrete half-cell in carbonated monoliths as a function of Fe content. Also, a consistent decrease in the relative fraction of Re within the soil half-cell was evident as a function of moisture content. Comparable behavior was previously observed in concrete-soil half-cell experiments wherein diffusion of I and Re from concrete to soil was quantified as a function of moisture content (Mattigod et al. 2001; Wellman et al. 2006). A similar trend for I was not evident in results of half-cell diffusion tests presented here. Rather, irrespective of moisture content, the fraction of I consistently ranged from 0.6 to 0.8 . At $7 \%$ and $15 \%$ moisture content, the relative fraction of I remaining within the sediment decreases as a function of moisture content. However, the fraction of I in sediment at $4 \%$ moisture content is highly variable and significantly less than that quantified for Re. Upon extraction of the half cells, it was noted that the inside walls of the PVC pipe were reddish-brown. It is hypothesized that vapor-phase diffusion of I onto the walls of the PVC pipe may have occurred at $4 \%$ moisture content. 
There was very minimal discoloration of the PVC walls noted at $7 \%$ and $15 \%$ moisture content. It appears that under higher moisture contents, the I may be remaining mostly in the aqueous phase; whereas, at very low moisture content (4\%), it tended to partially transform into vapor phase. To determine whether vapor-phase diffusion of I had occurred, 1:1 isopropyl alcohol extractions were conducted on slices of the PVC pipe. 200 to $850 \mathrm{ppb}$ I was extracted from various segments of the PVC pipes, whereas no measurable concentrations of Re were detected in the extracts.
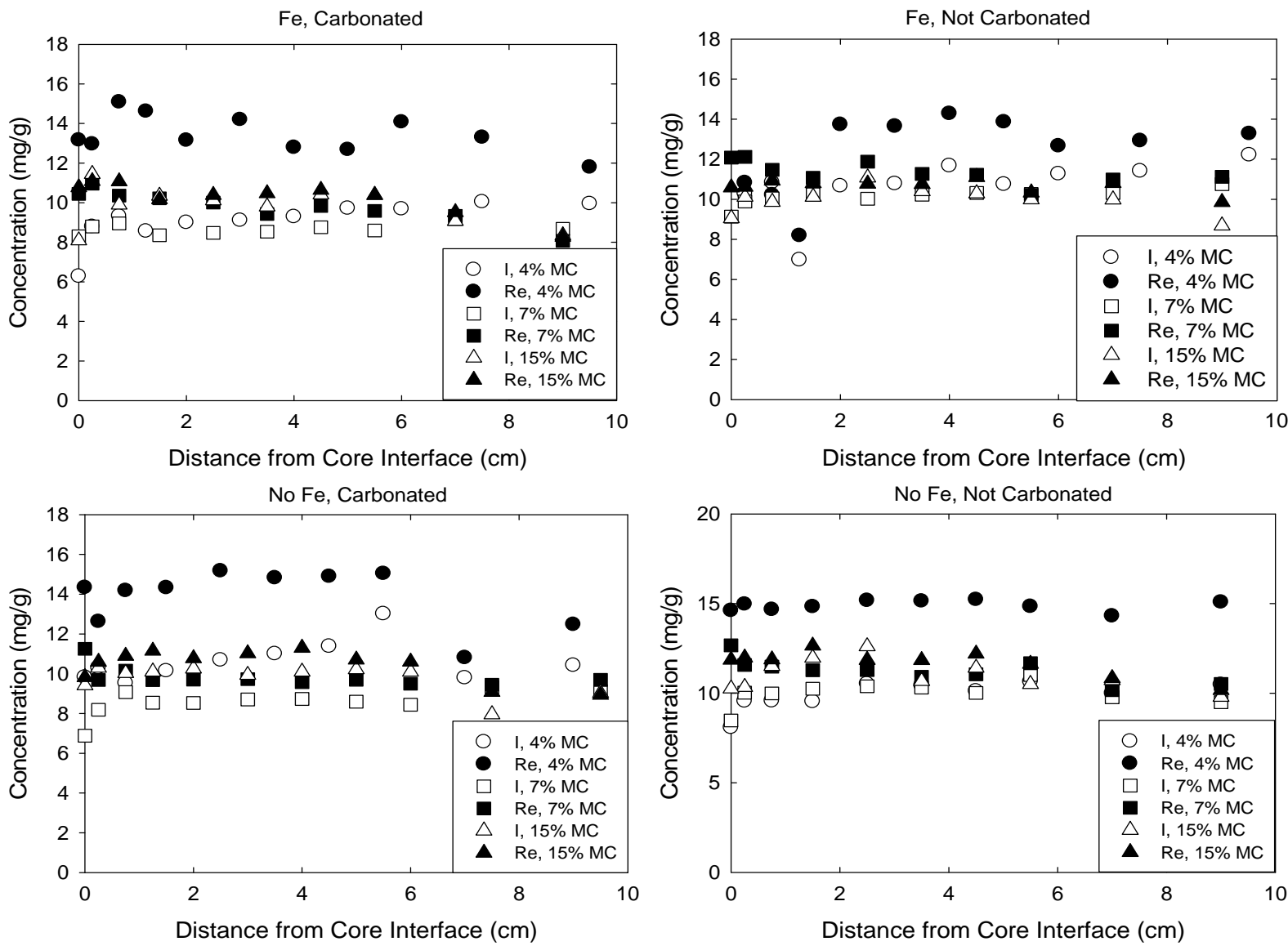

Figure 4.2. Concentration Profiles for Soil Half-Cell I and Re Profiles at 4\%, 7\%, and 15\% Moisture Content by Weight in a) Iron, Carbonated, b) Iron, Not Carbonated, c) No Iron, Carbonated, and d) No Iron, not Carbonated Concrete Monoliths. 

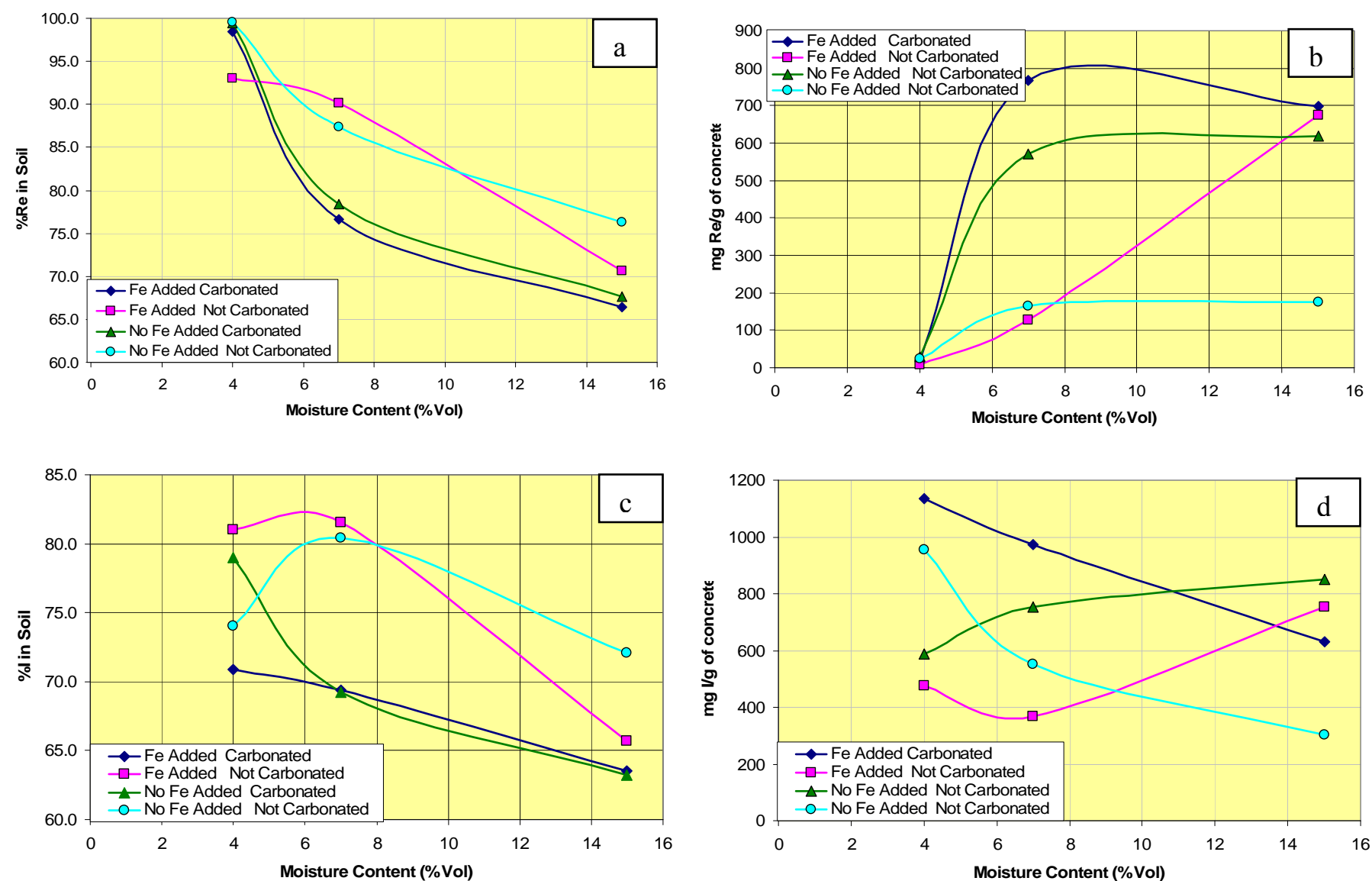

Figure 4.3. Mass Balance for Soil Half-Cell I and Re Profiles at 4\%, 7\%, and 15\% Moisture Content by Weight in a) Fraction of Re Remaining in Soil, b) Measured Mass of Re Diffused into Concrete, c) Fraction of I Remaining in Soi, and d) Measured Mass of I Diffused into Concrete.

Table 4-3. Concentration of Iodine (mg/g) for Soil Half-Cell Profiles at 4\%, 7\%, and 15\% Moisture Content by Weight

\begin{tabular}{|c|c|c|c|c|c|c|c|c|c|c|c|c||}
\hline $\begin{array}{l}\text { Distance } \\
\text { from } \\
\text { Core, cm }\end{array}$ & $\begin{array}{l}4 \% \\
\text { Fe-C }\end{array}$ & $\begin{array}{l}4 \% \\
\text { Fe- } \\
\text { NC }\end{array}$ & $\begin{array}{l}4 \% \\
\text { No } \\
\text { Fe-C }\end{array}$ & $\begin{array}{l}4 \% \\
\text { No } \\
\text { Fe- } \\
\text { NC }\end{array}$ & $\begin{array}{l}7 \% \\
\text { Fe-C }\end{array}$ & $\begin{array}{l}7 \% \\
\text { Fe- } \\
\text { NC }\end{array}$ & $\begin{array}{l}7 \% \\
\text { No } \\
\text { Fe-C }\end{array}$ & $\begin{array}{l}7 \% \\
\text { No } \\
\text { Fe- } \\
\text { NC }\end{array}$ & $\begin{array}{l}15 \% \\
\text { Fe-C }\end{array}$ & $\begin{array}{l}15 \% \\
\text { Fe- } \\
\text { NC }\end{array}$ & $\begin{array}{l}15 \% \\
\text { No } \\
\text { Fe-C }\end{array}$ & $\begin{array}{l}15 \% \\
\text { No } \\
\text { Fe- } \\
\text { NC }\end{array}$ \\
\hline \hline 9 & 9.9 & 12.2 & 10.4 & 10.5 & 8.7 & 10.8 & 9.1 & 9.5 & 8.4 & 8.7 & 9.0 & 9.8 \\
\hline 7 & 10.0 & 11.4 & 9.8 & 10.0 & 9.2 & 10.3 & 9.3 & 9.8 & 9.1 & 10.0 & 8.0 & 10.7 \\
\hline 5.5 & 9.7 & 11.3 & 13.0 & 10.6 & 8.6 & 10.3 & 8.4 & 11.0 & 10.4 & 10.0 & 10.1 & 10.5 \\
\hline 4.5 & 9.7 & 10.8 & 11.4 & 10.1 & 8.8 & 10.3 & 8.6 & 10.0 & 10.4 & 10.3 & 10.2 & 11.4 \\
\hline 3.5 & 9.3 & 11.7 & 11.0 & 10.4 & 8.5 & 10.2 & 8.7 & 10.3 & 9.8 & 10.4 & 10.1 & 10.7 \\
\hline 2.5 & 9.1 & 10.8 & 10.7 & 10.5 & 8.5 & 10.0 & 8.7 & 10.4 & 10.1 & 11.1 & 9.9 & 12.6 \\
\hline 1.5 & 9.0 & 10.7 & 10.1 & 9.5 & 8.4 & 10.3 & 8.5 & 10.2 & 10.3 & 10.1 & 10.3 & 12.0 \\
\hline 0.75 & 8.6 & 7.0 & 9.5 & 9.6 & 8.9 & 10.0 & 8.5 & 10.0 & 9.9 & 9.9 & 10.1 & 11.5 \\
\hline 0.25 & 9.3 & 10.8 & 10.3 & 9.6 & 8.8 & 9.9 & 9.1 & 10.0 & 11.4 & 10.1 & 10.0 & 10.3 \\
\hline Interface & 8.8 & 10.3 & 9.8 & 8.1 & 8.3 & 9.1 & 8.2 & 8.5 & 8.1 & 9.1 & 10.3 & 10.3 \\
\hline
\end{tabular}


Table 4-4. Concentration of Rhenium (mg/g) for Soil Half-Cell Profiles at 4\%, 7\%, and 15\% Moisture Content by Weight

\begin{tabular}{|c|l|l|l|l|l|l|l|l|l|l|l|l||}
\hline \hline $\begin{array}{l}\text { Distance } \\
\text { from } \\
\text { Core, cm }\end{array}$ & $\begin{array}{l}4 \% \\
\text { Fe-C }\end{array}$ & $\begin{array}{l}4 \% \\
\text { Fe- } \\
\text { NC }\end{array}$ & $\begin{array}{l}4 \% \\
\text { No } \\
\text { Fe-C }\end{array}$ & $\begin{array}{l}4 \% \\
\text { No } \\
\text { Fe- } \\
\text { NC }\end{array}$ & $\begin{array}{l}7 \% \\
\text { Fe-C }\end{array}$ & $\begin{array}{l}7 \% \\
\text { Fe- } \\
\text { NC }\end{array}$ & $\begin{array}{l}7 \% \\
\text { No } \\
\text { Fe-C }\end{array}$ & $\begin{array}{l}7 \% \\
\text { No } \\
\text { Fe- } \\
\text { NC }\end{array}$ & $\begin{array}{l}15 \% \\
\text { Fe-C }\end{array}$ & $\begin{array}{l}15 \% \\
\text { Fe- } \\
\text { NC }\end{array}$ & $\begin{array}{l}15 \% \\
\text { No } \\
\text { Fe-C }\end{array}$ & $\begin{array}{l}15 \% \\
\text { No } \\
\text { Fe- } \\
\text { NC }\end{array}$ \\
\hline \hline 9 & 11.8 & 13.3 & 12.5 & 15.1 & 8.1 & 11.1 & 9.7 & 10.5 & 8.3 & 9.9 & 8.9 & 10.2 \\
\hline 7 & 13.3 & 12.9 & 10.8 & 14.3 & 9.3 & 11.0 & 9.4 & 10.2 & 9.5 & 10.8 & 9.1 & 10.8 \\
\hline 5.5 & 14.1 & 12.7 & 15.0 & 14.8 & 9.6 & 10.2 & 9.5 & 11.7 & 10.4 & 10.3 & 10.6 & 11.6 \\
\hline 4.5 & 12.7 & 13.9 & 14.9 & 15.2 & 9.8 & 11.2 & 9.7 & 11.1 & 10.6 & 11.1 & 10.7 & 12.2 \\
\hline 3.5 & 12.8 & 14.3 & 14.8 & 15.1 & 9.4 & 11.3 & 9.6 & 10.9 & 10.5 & 10.8 & 11.3 & 11.8 \\
\hline 2.5 & 14.2 & 13.6 & 15.2 & 15.2 & 10.0 & 11.9 & 9.7 & 11.3 & 10.4 & 10.8 & 11.0 & 11.9 \\
\hline 1.5 & 13.2 & 13.7 & 14.3 & 14.8 & 10.2 & 11.1 & 9.7 & 11.3 & 10.2 & 10.8 & 10.8 & 12.6 \\
\hline 0.75 & 14.6 & 8.2 & 14.2 & 14.7 & 10.4 & 11.5 & 9.7 & 11.5 & 11.1 & 10.9 & 11.2 & 11.9 \\
\hline 0.25 & 15.1 & 10.2 & 12.6 & 15.0 & 11.0 & 12.1 & 10.2 & 11.6 & 11.1 & 10.6 & 10.9 & 12.0 \\
\hline Interface & 13.0 & 10.8 & 14.3 & 14.6 & 10.4 & 12.1 & 9.7 & 12.7 & 10.8 & 10.6 & 10.6 & 11.9 \\
\hline
\end{tabular}

Figure 4.4 and Table 4-5 displays plots showing the concentration profile for I and Re within the concrete half of the concrete-soil half-cell diffusion experiments at $4 \%$ moisture content. The behavior of I and Re were markedly different within a given half-cell test. The diffusion of I into concrete was 40 to $60 \mathrm{mg} / \mathrm{g}$ within the first $5 \mathrm{~mm}$ of the concrete half cell in contact with sediment. However, the diffusion of Re was limited to $<5 \mathrm{mg} / \mathrm{g}$ within the same depth of concrete. As noted above, it is hypothesized that vapor-phase diffusion of I may be occurring under conditions of $4 \%$ moisture content, which could afford greater diffusion of I into the concrete core. Additionally, the peak concentration of I at $4 \%$ moisture content in the concrete core has moved away from the interface. Qualitatively, it appears the concentration profiles may accord with variable diffusion rates the greatest rate being exhibited by the carbonate iron-bearing sample $>$ carbonate, iron-free sample $>$ non-carbonated, iron $>$ non-carbonated, iron-free sample. Also, the slight elevation in the concentration of Re at the interface of concrete monoliths not containing iron suggests iron may exert a limited influence on the diffusion of Re. Results of pending probit analyses will aid in this interpretation.

Figure 4.5, Table 4-6, and Table 4-7 illustrates the concentration profiles for I and Re within the concrete half of the concrete-soil half-cell diffusion experiments at $7 \%$ and $15 \%$ moisture content. The behavior of I and Re was generally comparable within a given half-cell test. The greatest concentration of I and Re were measured within the first $10 \mathrm{~mm}$ of the concrete monolith $(\sim 10-20 \mathrm{mg} / \mathrm{g})$ and there were gradual decreases in concentrations of both elements over the remaining 20 to $30 \mathrm{~mm}$ of concrete monolith. The noted exception to this was the concrete monoliths that contained no iron and were not carbonated. This set of concrete monoliths displayed a more rapid decrease in concentration within the first 10 to $20 \mathrm{~mm}$. As demonstrated previously, the inclusion of iron and the effect of carbonation result in the formation of microcracks within the concrete monoliths (Wellman et al. 2006) that apparently facilitate diffusion. The absence of iron in the uncarbonated core likely limited the potential formation of any microcracks, thus limiting diffusion of I and Re into the concrete monolith from the contaminated sediment. Increased micro-cracking in the presence of $\mathrm{Fe}$ and for concrete monoliths that had undergone carbonation agrees with results of previous investigations (Wellman et al. 2006). 
Fe, Carbonated

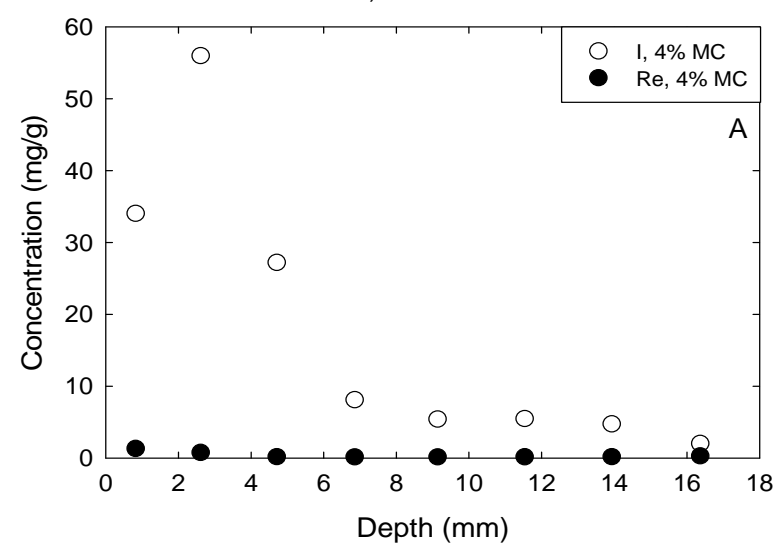

No Fe, Carbonated

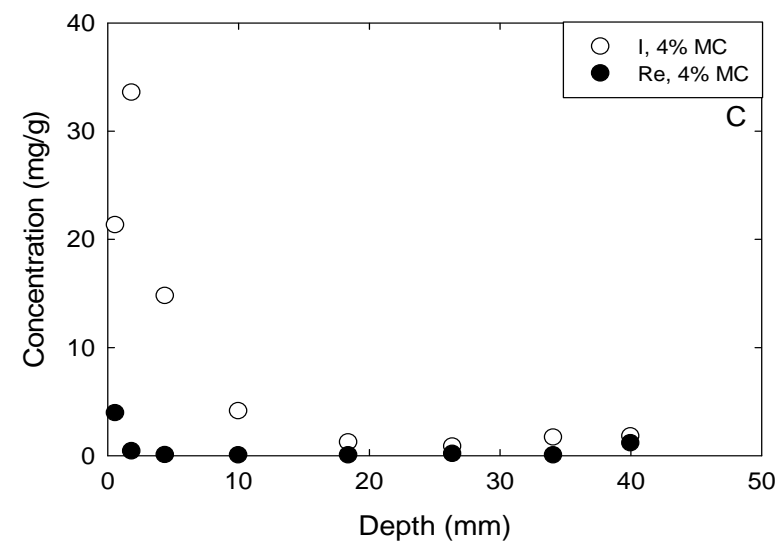

Fe, Not Carbonated

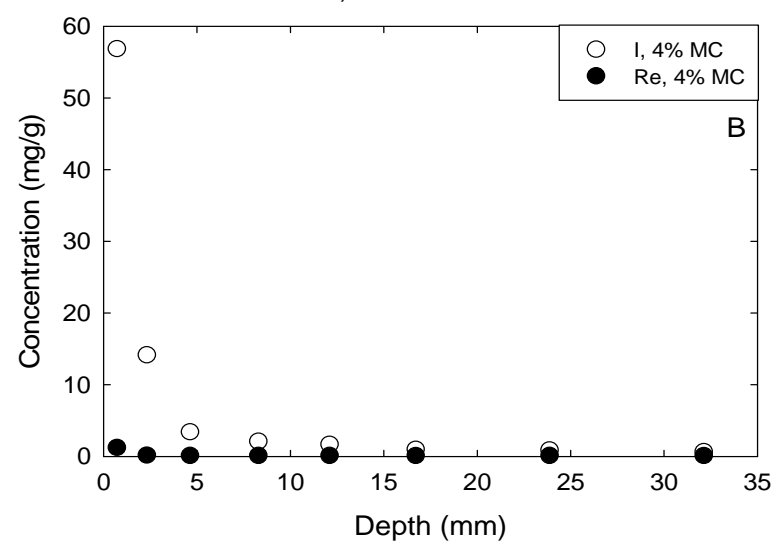

No Fe, Not Carbonated

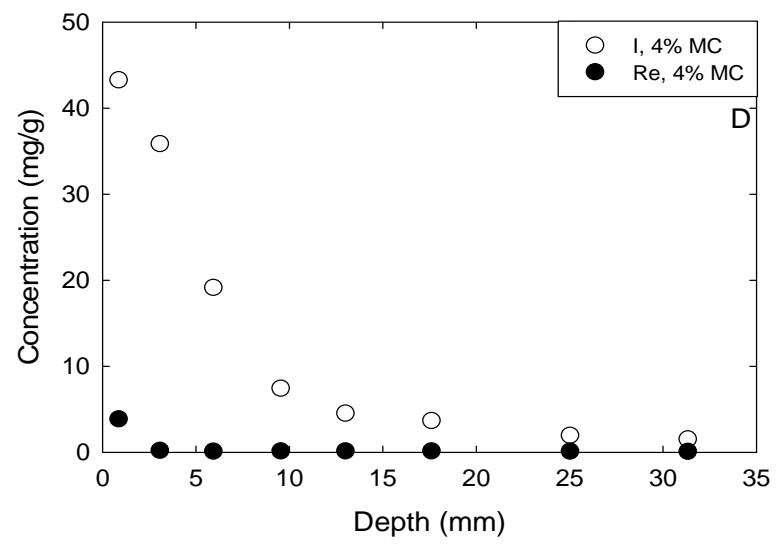

Figure 4.4. Concentration Profiles for Concrete Half-Cell I and Re Profiles at 4\% Moisture Content by Weight in a) Iron, Carbonated, b) Iron, Not Carbonated, c) No Iron, Carbonated, and d) No Iron, Not Carbonated Concrete Monoliths.

The concentrations of I and Re quantified within the monoliths were much lower at the interface than that measured at $4 \%$ moisture content $(40-60 \mathrm{mg} / \mathrm{g}$ at $4 \%$ moisture content versus $10-20 \mathrm{mg} / \mathrm{g}$ at $7 \%$ and $15 \%$ moisture content). Furthermore, the depth of diffusion of I and Re into the concrete monoliths was greater at higher moisture contents. At 4\% moisture content, the concentration of I was greatest within the first $5 \mathrm{~mm}$ and displayed a rapid asymptotic decrease in concentration to $\sim 1 \mathrm{mg} / \mathrm{g}$ within the first $10 \mathrm{~mm}$. The behavior of I and Re at $7 \%$ and $15 \%$ moisture content was generally greatest within the first $10 \mathrm{~mm}$, with a more gradual decrease over the remaining 20 to $30 \mathrm{~mm}$. This accords with previous results, suggesting a direct relationship between diffusion within concrete monoliths and the degree of moisture content (Wellman et al. 2006; Mattigod et al. 2001). However, the comparison of diffusion of I and Re at $7 \%$ and $15 \%$ shows a number of deviations. In the concrete monolith without iron and not carbonated, the diffusion of I appears to be more rapid at $7 \%$ than that observed at $15 \%$. Conversely, in the concrete monolith containing iron, but not carbonated the diffusion of iodine is noticeably greater than that at 7\%. This behavior is also evident for Re. Diffusion of I and Re in carbonated monoliths do not exhibit such deviations. Further investigation is necessary to understand these behaviors. 
Fe, Carbonated

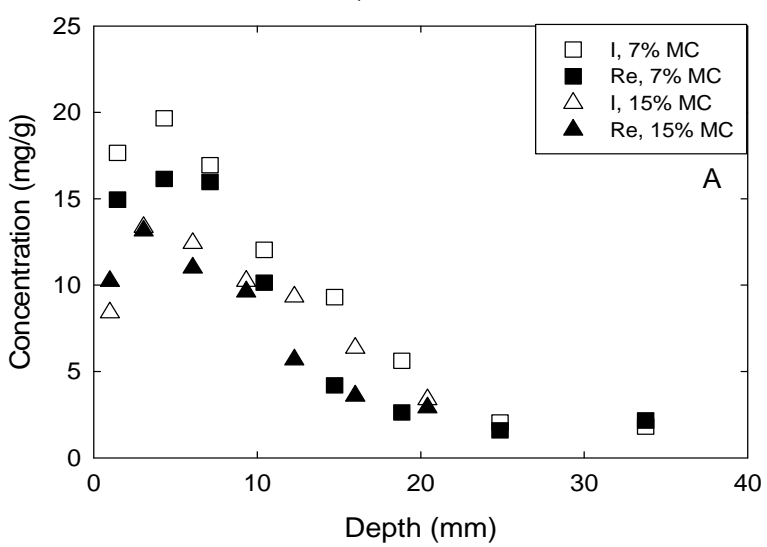

No Fe, Carbonated

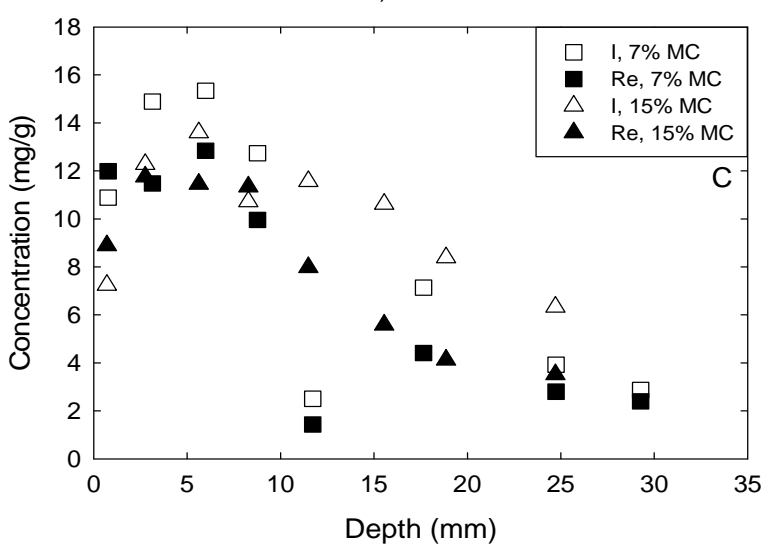

Fe, Not Carbonated

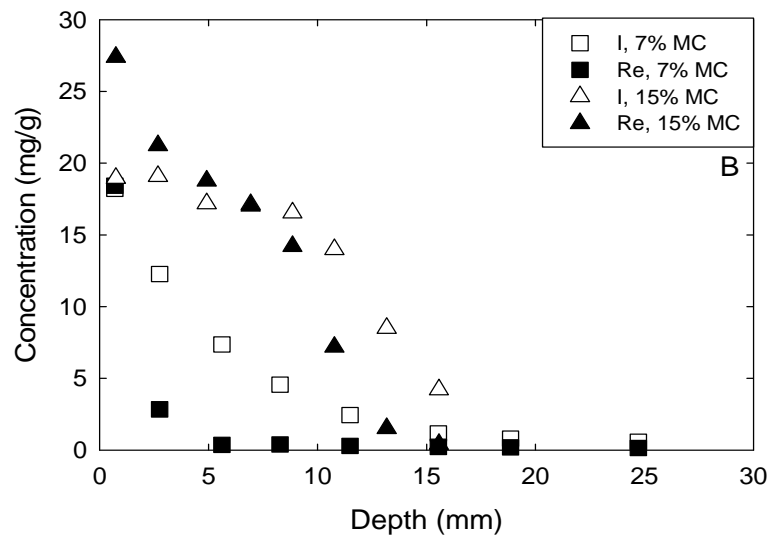

No Fe, Not Carbonated

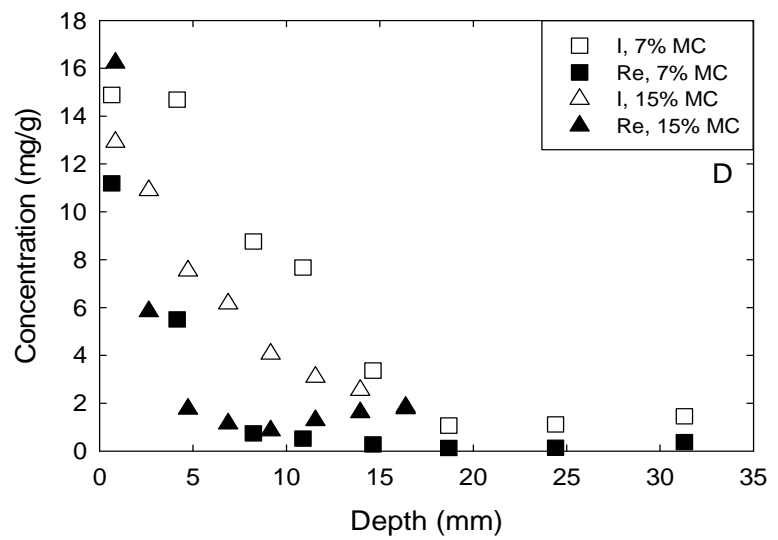

Figure 4.5. Concentration Profiles for Concrete Half-Cell I and Re Profiles at 7\%, and 15\% Moisture Content by Weight in a) Iron, Carbonated, b) Iron, Not Carbonated, c) No Iron, Carbonated, and d) No Iron, Not Carbonated Concrete Monoliths.

Table 4-5. Concentration of Iodine and Rhenium for Concrete Half-Cell Profiles at 4\% Moisture Content by Weight

\begin{tabular}{|c|c|c|c|c|c|c|c|c|c|c|c||}
\hline \multicolumn{3}{|c|}{$4 \% \mathrm{Fe}-\mathrm{C}$} & \multicolumn{3}{c|}{$4 \% \mathrm{Fe}-\mathrm{NC}$} & \multicolumn{3}{c|}{$4 \%$ No Fe-C } & \multicolumn{3}{c|}{$4 \%$ No Fe-NC } \\
\hline $\begin{array}{c}\text { Distance } \\
\text { from } \\
\begin{array}{c}\text { Interface, } \\
\mathrm{mm}\end{array}\end{array}$ & $\begin{array}{c}\mathrm{I}, \\
\mathrm{mg} / \mathrm{g}\end{array}$ & $\begin{array}{c}\mathrm{Re} \\
\mathrm{mg} / \mathrm{g}\end{array}$ & $\begin{array}{c}\text { Distance } \\
\text { from } \\
\text { Interface, } \\
\mathrm{mm}\end{array}$ & $\begin{array}{c}\mathrm{I}, \\
\mathrm{mg} / \mathrm{g}\end{array}$ & $\begin{array}{c}\mathrm{Re} \\
\mathrm{mg} / \mathrm{g}\end{array}$ & $\begin{array}{c}\text { Distance } \\
\text { from } \\
\text { Interface, } \\
\mathrm{mm}\end{array}$ & $\begin{array}{c}\mathrm{I}, \\
\mathrm{mg} / \mathrm{g}\end{array}$ & $\begin{array}{c}\mathrm{Re} \\
\mathrm{mg} / \mathrm{g}\end{array}$ & $\begin{array}{c}\text { Distance } \\
\text { from } \\
\text { Interface, } \\
\mathrm{mm}\end{array}$ & $\begin{array}{c}\mathrm{I}, \\
\mathrm{mg} / \mathrm{g}\end{array}$ & $\begin{array}{c}\mathrm{Re} \\
\mathrm{mg} / \mathrm{g}\end{array}$ \\
\hline \hline 1.3 & 33.93 & 1.23 & 1.5 & 56.79 & 1.13 & 1.2 & 21.28 & 3.90 & 1.8 & 43.20 & 3.78 \\
\hline 2.9 & 55.87 & 0.69 & 3.21 & 14.07 & 0.08 & 2.51 & 33.53 & 0.38 & 4.41 & 35.78 & 0.12 \\
\hline 6.1 & 27.11 & 0.10 & 6.12 & 3.32 & 0.03 & 6.32 & 14.73 & 0.02 & 7.52 & 19.06 & 0.03 \\
\hline 9.2 & 8.01 & 0.06 & 10.53 & 2.01 & 0.02 & 13.73 & 4.08 & 0.00 & 11.63 & 7.36 & 0.04 \\
\hline 13.8 & 5.34 & 0.06 & 13.74 & 1.59 & 0.02 & 23.14 & 1.20 & 0.00 & 14.44 & 4.46 & 0.07 \\
\hline 18.5 & 5.39 & 0.08 & 19.75 & 0.89 & 0.02 & 29.65 & 0.82 & 0.13 & 20.85 & 3.59 & 0.07 \\
\hline 27.1 & 4.66 & 0.09 & 28.06 & 0.80 & 0.02 & 38.56 & 1.65 & 0.01 & 29.26 & 1.87 & 0.03 \\
\hline 35.2 & 1.93 & 0.19 & 36.27 & 0.56 & 0.01 & 41.47 & 1.76 & 1.12 & 33.47 & 1.45 & 0.01 \\
\hline
\end{tabular}


Table 4-6. Concentration of Iodine and Rhenium for Concrete Half-Cell Profiles at 7\% Moisture Content by Weight

\begin{tabular}{|c|c|c|c|c|c|c|c|c|c|c|c||}
\hline \multicolumn{3}{|c|}{$7 \%$ Fe-C } & \multicolumn{3}{c|}{$7 \%$ Fe-NC } & \multicolumn{3}{c|}{$7 \%$ No Fe-C } & \multicolumn{3}{c|}{$7 \%$ No Fe-NC } \\
\hline $\begin{array}{c}\text { Distance } \\
\text { from } \\
\begin{array}{c}\text { Interface, } \\
\mathrm{mm}\end{array}\end{array}$ & $\begin{array}{c}\mathrm{I}, \\
\mathrm{mg} / \mathrm{g}\end{array}$ & $\begin{array}{c}\mathrm{Re} \\
\mathrm{mg} / \mathrm{g}\end{array}$ & $\begin{array}{c}\text { Distance } \\
\text { from } \\
\text { Interface, } \\
\mathrm{mm}\end{array}$ & $\begin{array}{c}\mathrm{I}, \\
\mathrm{mg} / \mathrm{g}\end{array}$ & $\begin{array}{c}\mathrm{Re} \\
\mathrm{mg} / \mathrm{g}\end{array}$ & $\begin{array}{c}\text { Distance } \\
\text { from } \\
\text { Interface, } \\
\mathrm{mm}\end{array}$ & $\begin{array}{c}\mathrm{I}, \\
\mathrm{mg} / \mathrm{g}\end{array}$ & $\begin{array}{c}\mathrm{Re} \\
\mathrm{mg} / \mathrm{g}\end{array}$ & $\begin{array}{c}\text { Distance } \\
\text { from } \\
\text { Interface, } \\
\mathrm{mm}\end{array}$ & $\begin{array}{c}\mathrm{I}, \\
\mathrm{mg} / \mathrm{g}\end{array}$ & $\begin{array}{c}\mathrm{Re} \\
\mathrm{mg} / \mathrm{g}\end{array}$ \\
\hline \hline 2.9 & 17.65 & 14.95 & 1.4 & 18.21 & 18.42 & 1.54 & 10.89 & 11.99 & 1.3 & 14.89 & 11.19 \\
\hline 5.71 & 19.66 & 16.14 & 4.11 & 12.27 & 2.84 & 4.74 & 14.89 & 11.47 & 6.99 & 14.69 & 5.50 \\
\hline 8.52 & 16.94 & 15.96 & 7.12 & 7.36 & 0.36 & 7.24 & 15.34 & 12.84 & 9.46 & 8.76 & 0.74 \\
\hline 12.33 & 12.04 & 10.14 & 9.43 & 4.56 & 0.39 & 10.29 & 12.74 & 9.96 & 12.3 & 7.67 & 0.52 \\
\hline 17.14 & 9.30 & 4.20 & 13.54 & 2.44 & 0.30 & 13.15 & 2.50 & 1.43 & 16.96 & 3.37 & 0.28 \\
\hline 20.55 & 5.62 & 2.62 & 17.55 & 1.17 & 0.23 & 22.17 & 7.13 & 4.41 & 20.41 & 1.07 & 0.13 \\
\hline 29.16 & 2.05 & 1.59 & 20.16 & 0.80 & 0.20 & 27.33 & 3.92 & 2.80 & 28.4 & 1.12 & 0.14 \\
\hline 38.37 & 1.81 & 2.16 & 29.27 & 0.58 & 0.15 & 31.22 & 2.87 & 2.40 & 34.2 & 1.46 & 0.38 \\
\hline
\end{tabular}

Table 4-7. Concentration of Iodine and Rhenium for Concrete Half-Cell Profiles at $15 \%$ Moisture Content by Weight

\begin{tabular}{|c|c|c|c|c|c|c|c|c|c|c|c||}
\hline \multicolumn{3}{|c|}{$15 \% \mathrm{Fe}-\mathrm{C}$} & \multicolumn{3}{c|}{$15 \% \mathrm{Fe}-\mathrm{NC}$} & \multicolumn{3}{c|}{$15 \%$ No Fe-C } & \multicolumn{3}{c|}{$15 \%$ No Fe-NC } \\
\hline $\begin{array}{c}\text { Distance } \\
\text { from } \\
\begin{array}{c}\text { Interface, } \\
\mathrm{mm}\end{array}\end{array}$ & $\begin{array}{c}\mathrm{I}, \\
\mathrm{mg} / \mathrm{g}\end{array}$ & $\begin{array}{c}\mathrm{Re} \\
\mathrm{mg} / \mathrm{g}\end{array}$ & $\begin{array}{c}\text { Distance } \\
\text { from } \\
\text { Interface, } \\
\mathrm{mm}\end{array}$ & $\begin{array}{c}\mathrm{I}, \\
\mathrm{mg} / \mathrm{g}\end{array}$ & $\begin{array}{c}\mathrm{Re} \\
\mathrm{mg} / \mathrm{g}\end{array}$ & $\begin{array}{c}\text { Distance } \\
\text { from } \\
\text { Interface, } \\
\mathrm{mm}\end{array}$ & $\begin{array}{c}\mathrm{I}, \\
\mathrm{mg} / \mathrm{g}\end{array}$ & $\begin{array}{c}\mathrm{Re} \\
\mathrm{mg} / \mathrm{g}\end{array}$ & $\begin{array}{c}\text { Distance } \\
\text { from } \\
\text { Interface, } \\
\mathrm{mm}\end{array}$ & $\begin{array}{c}\mathrm{I}, \\
\mathrm{mg} / \mathrm{g}\end{array}$ & $\begin{array}{c}\mathrm{Re} \\
\mathrm{mg} / \mathrm{g}\end{array}$ \\
\hline \hline 1.97 & 8.41 & 10.22 & 1.49 & 18.95 & 27.39 & 1.4 & 7.25 & 8.89 & 1.69 & 12.91 & 16.22 \\
\hline 4.14 & 13.35 & 13.15 & 3.87 & 19.08 & 21.22 & 4.11 & 12.28 & 11.76 & 3.58 & 10.90 & 5.83 \\
\hline 7.96 & 12.42 & 11.01 & 5.95 & 17.18 & 18.77 & 7.12 & 13.60 & 11.45 & 5.88 & 7.54 & 1.77 \\
\hline 10.69 & 10.23 & 9.62 & 7.91 & 17.13 & 17.02 & 9.43 & 10.73 & 11.34 & 7.87 & 6.16 & 1.15 \\
\hline 13.85 & 9.32 & 5.68 & 9.78 & 16.54 & 14.21 & 13.54 & 11.57 & 7.98 & 10.44 & 4.07 & 0.86 \\
\hline 18.14 & 6.35 & 3.59 & 11.77 & 13.99 & 7.19 & 17.55 & 10.62 & 5.58 & 12.67 & 3.09 & 1.28 \\
\hline 22.68 & 3.38 & 2.91 & 14.57 & 8.51 & 1.53 & 20.16 & 8.39 & 4.12 & 15.23 & 2.55 & 1.62 \\
\hline- & - & - & 16.56 & 4.22 & 0.42 & 29.27 & 6.33 & 3.51 & 17.54 & 1.84 & 1.77 \\
\hline
\end{tabular}




\subsection{Effect of Iron on the Release of Rhenium, Iodine, and Technetium from Concrete}

\subsection{Dynamic Leach Test}

The dynamic leach test is a American National Standards Institute (ANSI)-16.1 standard test that is designed to examine the leaching rate of contaminants in concrete and grout specimens to determine the cumulative fractions leached and effective diffusion coefficients. These tests were conducted according to protocol specified by ANSI (2004).

Based on the laboratory concrete composition presented in Table 3-2, a set of concrete monoliths, spiked with 1) I and Re, or 2) I and Tc, were prepared with $4 \%, 8 \%$, and $12 \%$ by mass, respectively, of metallic iron particles. Iron particles consisted of metallic iron ( -40 to +60 mesh) and reactive nanoscale zero valent iron particles (RNIP) (Toda America, Inc Schaumburg, IL). The characteristics of the specimens used are listed in Table 5-1.

Table 5-1. Characteristics of Cement Specimens Used in ANSI Dynamic Leach Tests

\begin{tabular}{|c|c|c|c|c|c|c|c|c|c|c|c|c|}
\hline \multirow[b]{2}{*}{$\begin{array}{c}\text { Specimen } \\
\text { No. }\end{array}$} & \multirow[b]{2}{*}{$\begin{array}{l}\text { Length } \\
(\mathrm{cm})\end{array}$} & \multirow[b]{2}{*}{$\begin{array}{l}\text { Diameter } \\
(\mathrm{cm})\end{array}$} & \multirow{2}{*}{$\begin{array}{l}\text { Surface } \\
\text { Area } \\
\left(\mathrm{cm}^{2}\right)\end{array}$} & \multirow[b]{2}{*}{$\begin{array}{c}\text { Volume } \\
\left(\mathrm{cm}^{3}\right)\end{array}$} & \multicolumn{5}{|c|}{ Iron } & \multicolumn{3}{|c|}{ Contaminant } \\
\hline & & & & & Metal & RNIP & $4 \%$ & $8 \%$ & $12 \%$ & $\mathrm{I}$ & $\mathrm{Re}$ & $\mathrm{Tc}$ \\
\hline 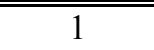 & 3.67 & 2.50 & 38.65 & 18.02 & 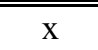 & & $\bar{x}$ & & & 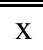 & $\overline{\mathrm{x}}$ & \\
\hline 2 & 3.15 & 2.49 & 34.48 & 15.41 & $\mathrm{x}$ & & & $\mathrm{x}$ & & $\mathrm{x}$ & $\mathrm{x}$ & \\
\hline 3 & 3.96 & 2.51 & 40.99 & 19.50 & $\mathrm{x}$ & & & & $\mathrm{x}$ & $\mathrm{x}$ & $\mathrm{x}$ & \\
\hline 4 & 4.50 & 2.50 & 45.17 & 22.06 & & $\mathrm{x}$ & $\mathrm{x}$ & & & $\mathrm{x}$ & $\mathrm{x}$ & \\
\hline 5 & 4.18 & 2.51 & 42.87 & 20.70 & & $\mathrm{x}$ & & $\mathrm{x}$ & & $\mathrm{x}$ & $\mathrm{x}$ & \\
\hline 6 & 4.44 & 2.51 & 44.91 & 21.96 & & $\mathrm{x}$ & & & $\mathrm{x}$ & $\mathrm{x}$ & $\mathrm{x}$ & \\
\hline 7 & 4.48 & 2.52 & 45.32 & 22.25 & & $\mathrm{x}$ & $\mathrm{x}$ & & & $\mathrm{x}$ & & $\mathrm{x}$ \\
\hline 8 & 4.39 & 2.49 & 44.12 & 21.41 & & $\mathrm{x}$ & & $\mathrm{x}$ & & $\mathrm{x}$ & & $x$ \\
\hline 9 & 4.22 & 2.50 & 42.86 & 20.64 & & $\mathrm{x}$ & & & $\mathrm{x}$ & $\mathrm{x}$ & & $\mathrm{x}$ \\
\hline
\end{tabular}

The concrete monoliths were subjected to dynamic leach tests (ANSI-16.1) to determine the rate of leaching of I, Re, and Tc in concrete, based on the inclusion of iron, and to determine the cumulative fraction leached and effective diffusion coefficient. The test protocol was slightly modified in that actual groundwater from the Hanford Site was used as the leachant instead of the demineralized water specified in ANSI-16.1. The composition of Hanford Site groundwater is listed in Table 5-2.

\subsection{Effective Diffusivity Calculations}

Based on a number of leach studies, Serne et al. (1992a, 1995) concluded that leaching from a semiinfinite solid source would be the most appropriate model to describe the release of trace contaminants from grout and cement specimens. Seven critical assumptions in their model were:

- The concentration of leaching contaminant species at the surface of the specimen is always zero; i.e., the contaminant is instantaneously removed by the liquid as soon as the species diffusing from the solid reaches the solid-liquid interface. 
Table 5-2. Composition of Typical Hanford Groundwater

\begin{tabular}{||c|c||}
\hline Cation & Concentration, $\mathrm{mg} \mathrm{L}^{-1}$ \\
\hline \hline $\mathrm{Ba}$ & 0.043 \\
\hline $\mathrm{Ca}$ & 35.27 \\
\hline $\mathrm{Fe}$ & 0.14 \\
\hline $\mathrm{K}$ & 15.19 \\
\hline $\mathrm{Mg}$ & 27.29 \\
\hline $\mathrm{P}$ & $<0.025$ \\
\hline $\mathrm{Sr}$ & 0.14 \\
\hline $\mathrm{Na}$ & 73.71 \\
\hline $\mathrm{Si}$ & 35.37 \\
\hline $\mathrm{S}$ & 56.65 \\
\hline $\mathrm{F}^{-}$ & 0.83 \\
\hline $\mathrm{Cl}^{-}$ & 12.24 \\
\hline $\mathrm{CO}_{3}{ }^{2-}$ & 191.59 \\
\hline $\mathrm{SO}_{4}{ }^{3-}$ & 167.28 \\
\hline $\mathrm{pH}^{-}$ & 8.12 \\
\hline
\end{tabular}

- The composition of the liquid in contact with the solid being leached is constant. This implies that the leaching contaminant will not significantly change the liquid composition.

- The solid waste form does not alter physically or chemically during the leaching process. A critical part of this assumption is that the mass of constituents leached is insignificant when compared to the total mass of these constituents in the solid, thus fulfilling the semi-infinite solid requirement.

- The surface area of the solid is constant and does not change by armoring (i.e., formation of a protective layer during leaching).

- Any chemical reaction is rapid enough so that chemical equilibrium always exists between leaching species in the solid and the liquid.

- Each contaminant exists as a single chemical species such as all free, cationic, anionic, or neutral) or in a complexed form (either a single cationic, anionic, or neutral species).

- Bulk diffusion is the rate-limiting process for contaminant leaching.

Leaching of semi-infinite solids has been described mathematically using either incremental leach rates or cumulative leach rates (Serne et al. 1992a, b; 1995). Using incremental leach rates, the effective diffusion coefficient for each leach interval $\left(D_{\mathrm{ei}}\right)$ for a species of interest is expressed as:

$$
D_{e i}=\pi\left[\left(\frac{a_{n}}{A_{o}}\right) / \Delta t_{n}\right]^{2}\left[\frac{V}{S}\right]^{2}[T]
$$

Using cumulative leaching rates, the effective diffusion coefficient $\left(\mathrm{D}_{\mathrm{ec}}\right)$ is expressed as:

$$
D_{e i}=\pi / 4\left[\left(\frac{\sum a_{n}}{A_{o}}\right) / \Delta t_{n}\right]^{2}\left[\frac{V}{S}\right]^{2}\left[\frac{1}{t}\right]
$$


where

$D_{e i}=$ effective diffusivity coefficient $\left(\mathrm{cm}^{2} / \mathrm{s}\right)$ for the leaching interval, $\mathrm{t}_{\mathrm{n}}-\mathrm{t}_{\mathrm{n}-1}$

$D_{e c}=$ effective diffusivity coefficient $\left(\mathrm{cm}^{2} / \mathrm{s}\right)$ for the cumulative leach interval, $\mathrm{t}_{\mathrm{n}}-\mathrm{t}_{\mathrm{o}}$

$a_{n}=$ activity of radionuclide leached during the leaching interval, $\mathrm{t}_{\mathrm{n}}-\mathrm{t}_{\mathrm{n}-1}$

$\Sigma a_{n}=$ total activity of radionuclide cumulatively leached during the interval, $\mathrm{t}_{\mathrm{n}}-\mathrm{t}_{\mathrm{o}}$

$A_{o}=$ total initial activity of radionuclide in the specimen

$a_{n} / A_{o} \quad=$ fraction of radionuclide leached during interval, $\mathrm{t}_{\mathrm{n}}-\mathrm{t}_{\mathrm{n}-1}$

$\frac{\Sigma a_{n}}{A_{o}}=$ cumulative fraction of radionuclide leached during the interval $\mathrm{t}_{\mathrm{n}}-\mathrm{t}_{\mathrm{o}}$

$\Delta \mathrm{t}_{\mathrm{n}}=$ duration of the $\mathrm{nth}$ leaching interval, $\mathrm{t}_{\mathrm{n}}-\mathrm{t}_{\mathrm{n}-1}$ in seconds

$V=$ volume of the specimen, $\mathrm{cm}^{3}$

$S=$ geometric surface area of the specimen, $\mathrm{cm}^{2}$

$T=$ mean leaching time $=\left[\frac{1}{2\left(\sqrt{t_{n}}+\sqrt{t_{n-1}}\right)}\right]^{2}$

$t=$ total elapsed time from leaching initiation in seconds.

According to Serne et al (1992a, b; 1995), if the leach experiments satisfy all the seven conditions listed above for semi-infinite solids, both equations 3.1 and 3.2) would provide the same effective diffusion coefficient for all times. However, in actual leaching experiments, many of the conditions cannot be met; therefore, the calculated average $D_{e i}$ and $D_{e c}$ are different. For instance, Serne et al. (1992a, b; 1995) observed that armoring is a common phenomena in leach studies of cement specimens, which would affect the leach rates depending on the rate of formation, thickness, and the chemical nature of surface armoring. Additionally, certain species may leach out in sufficient quantities, which would invalidate the third assumption of insignificant leach fraction. Also, a number of chemical speciation studies have indicated that in cement specimens, each leaching species does not exist as a single chemical species. Therefore, the assumption of single diffusing chemical species may not be valid.

In leaching experiments where the leaching fraction of a species is significant $(>20 \%$ the amount contained initially in a specimen), the ANSI protocol recommends a specimen shape-specific solution of the mass transport equation. The effective diffusion coefficient in this case for a cylindrical specimen is calculated by using the equation:

$$
D_{e c}=\frac{G d^{2}}{t}
$$

where

$G=$ a dimensionless time factor for the cylinder

$d=$ the diameter of the cylinder in $\mathrm{cm}$

$t=$ total elapsed time from leaching initiation in seconds. 
The average effective diffusion coefficients were calculated from the values determined for each leaching interval $\left(D_{e i}\right)$ and each cumulative leach time $\left(D_{e c}\right)$. The leachability index for each radionuclide was calculated from the average effective diffusion coefficient values as:

$$
\mathrm{L}=\log \left(\beta / \mathrm{D}_{\mathrm{e}}\right)
$$

where

$L \quad=$ leachability index

$\beta=$ a constant $=1 \mathrm{~cm}^{2} / \mathrm{s}$

$D_{e}=$ average effective diffusion coefficient.

\subsection{Results and Discussion}

Figure 5.1 presents the cumulative fraction of I, Re, and Tc, respectively, released as a function of time during dynamic leach testing. The results indicate that in the dynamic leach test all contaminants leach rapidly during the first 5 days. Subsequent release continued at an attenuated rate for the remainder of the test for all contaminants.
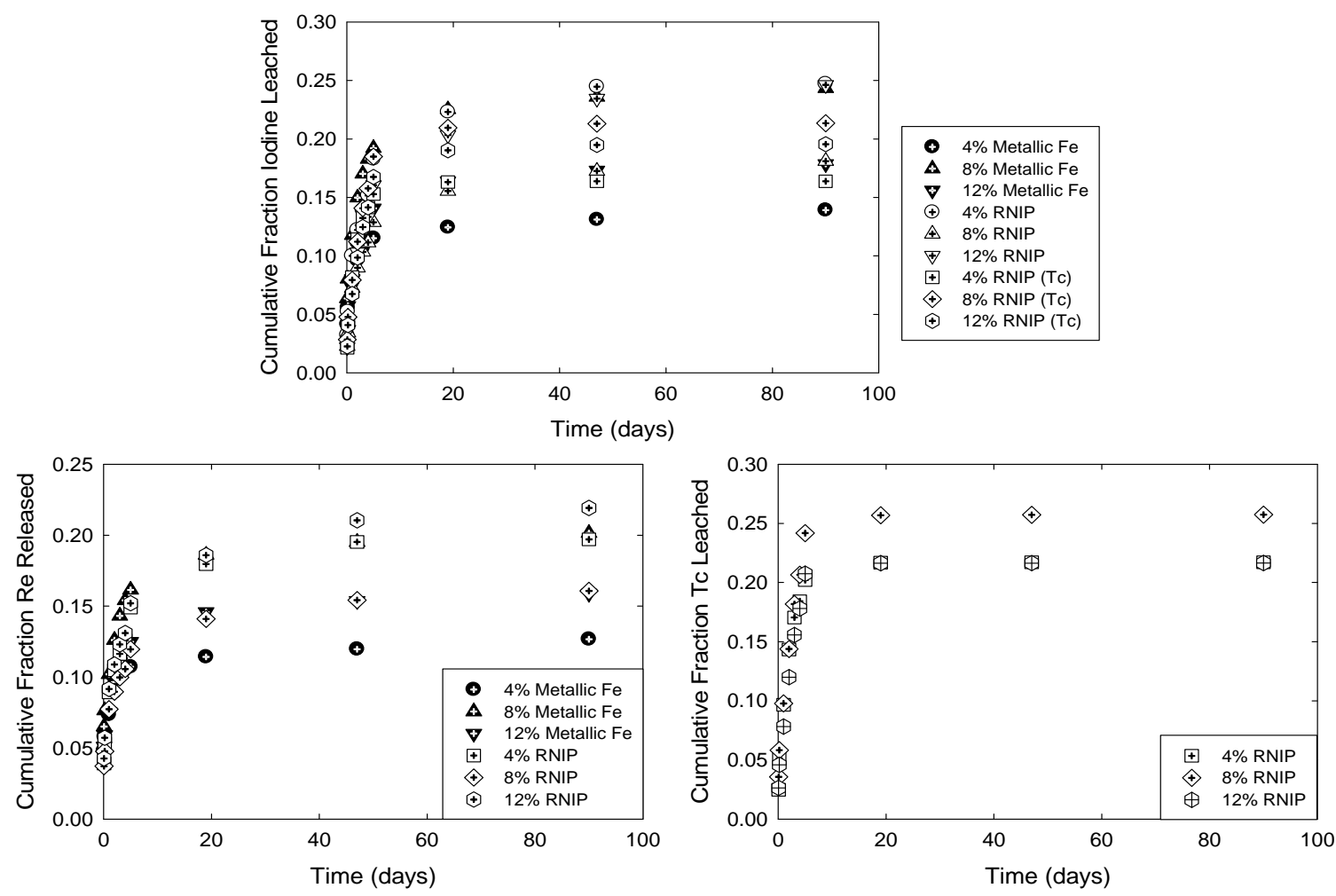

Figure 5.1. Dynamic Leach Test: Cumulative Leaching Fraction as a Function of Time for I, Re, and Tc

Table 5-3 presents the effective diffusion coefficient for I and Re at $4 \%, 8 \%$, and $12 \%$ iron, as metallic iron (-40 to +60 mesh) and RNIP. The leaching indices indicate that the presence of metallic iron particles or RNIP in concentrations ranging from $4 \%$ to $12 \%$ by mass did not significantly affect the leachability of Re and I from waste-form specimens. However, inclusion of RNIP relative to metallic iron particles significantly increases the leachability of Re and I from waste-form specimens. The leaching behavior of I and Re in the presence of RNIP was at a significantly increased rate throughout the duration of the test. The RNIP formulation consists of elemental iron, magnetite, water, and a water soluble polymer to maintain a stabilized iron slurry. It is hypothesized that the polymer may form a 
surface coating on the iron particles which reduces their reactivity and may inhibit reaction with redoxsensitive contaminants within the concrete waste forms.

Table 5-3. Leach Index Data for Re and I as a Functions of Metallic Iron-Particle Concentration ${ }^{1}$

\begin{tabular}{|c|c|c|c|c|c|c|c|c|}
\hline \multirow[b]{2}{*}{ Time Hr } & \multicolumn{4}{|c|}{$\mathrm{Re} / \mathrm{I}$ concrete column with $4 \% \mathrm{Fe}$} & \multicolumn{4}{|c|}{ Re/I concrete column with $4 \%$ ZVI } \\
\hline & $\mathrm{Re}$ & I & $\begin{array}{l}\text { Leach } \\
\text { index }\end{array}$ & $\begin{array}{l}\text { Leach } \\
\text { index }\end{array}$ & $\mathrm{Re}$ & I & $\mathrm{Re}$ & I \\
\hline & $\mathrm{D}$ eff $\mathrm{cm}^{2} / \mathrm{s}$ & $\mathrm{D}$ eff $\mathrm{cm}^{2} / \mathrm{s}$ & $\mathrm{Re}$ & I & $\mathrm{D}$ eff $\mathrm{cm}^{2} / \mathrm{s}$ & $\mathrm{D}$ eff $\mathrm{cm}^{2} / \mathrm{s}$ & Leach index & Leach index \\
\hline 2 & $2.20 \mathrm{E}-07$ & $1.64 \mathrm{E}-07$ & 6.7 & 6.8 & $1.6 \mathrm{E}-07$ & $1.1 \mathrm{E}-07$ & 6.80 & 6.96 \\
\hline 7 & $2.00 \mathrm{E}-09$ & $4.31 \mathrm{E}-09$ & 8.7 & 8.4 & $4.5 \mathrm{E}-09$ & $9.3 \mathrm{E}-09$ & 8.34 & 8.03 \\
\hline 24 & $1.94 \mathrm{E}-09$ & $3.55 \mathrm{E}-09$ & 8.7 & 8.4 & $1.1 \mathrm{E}-08$ & $2.0 \mathrm{E}-08$ & 7.95 & 7.71 \\
\hline 48 & $8.63 \mathrm{E}-10$ & $1.35 \mathrm{E}-09$ & 9.1 & 8.9 & $9.8 \mathrm{E}-10$ & 2.0E-09 & 9.01 & 8.70 \\
\hline 72 & $3.39 \mathrm{E}-10$ & $2.77 \mathrm{E}-10$ & 9.5 & 9.6 & $3.6 \mathrm{E}-10$ & $7.7 \mathrm{E}-10$ & 9.44 & 9.11 \\
\hline 96 & $3.35 \mathrm{E}-11$ & $5.54 \mathrm{E}-11$ & 10.5 & 10.3 & $1.9 \mathrm{E}-10$ & $3.4 \mathrm{E}-10$ & 9.72 & 9.47 \\
\hline 120 & $8.88 \mathrm{E}-12$ & $1.29 \mathrm{E}-11$ & 11.1 & 10.9 & $9.2 \mathrm{E}-10$ & $1.7 \mathrm{E}-09$ & 9.04 & 8.78 \\
\hline 456 & $2.38 \mathrm{E}-11$ & $4.19 \mathrm{E}-11$ & 10.6 & 10.4 & $5.1 \mathrm{E}-10$ & $8.8 \mathrm{E}-10$ & 9.29 & 9.06 \\
\hline 1200 & $4.70 \mathrm{E}-12$ & $7.16 \mathrm{E}-12$ & 11.3 & 11.1 & $4.0 \mathrm{E}-11$ & $7.7 \mathrm{E}-11$ & 10.40 & 10.11 \\
\hline \multirow[t]{3}{*}{2208} & $4.12 \mathrm{E}-12$ & $5.44 \mathrm{E}-12$ & 11.4 & 11.3 & $2.9 \mathrm{E}-13$ & $5.7 \mathrm{E}-13$ & 12.53 & 12.25 \\
\hline & & ${ }^{1} \mathrm{~L}$ bar $=$ & 9.7 & 9.6 & & ${ }^{1} \mathrm{~L}$ bar $=$ & 9.3 & 9.0 \\
\hline & \multicolumn{4}{|c|}{ 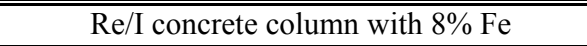 } & \multicolumn{4}{|c|}{ "Re/I concrete column with $8 \%$ ZVI } \\
\hline Time Hr & $\operatorname{Re}$ & I & $\begin{array}{l}\text { Leach } \\
\text { index }\end{array}$ & $\begin{array}{l}\text { Leach } \\
\text { index }\end{array}$ & $\operatorname{Re}$ & I & $\operatorname{Re}$ & I \\
\hline & $\mathrm{D}$ eff $\mathrm{cm}^{2} / \mathrm{s}$ & $\mathrm{D}$ eff $\mathrm{cm}^{2} / \mathrm{s}$ & $\operatorname{Re}$ & $\mathrm{I}$ & $\mathrm{D}$ eff $\mathrm{cm}^{2} / \mathrm{s}$ & $\mathrm{D}$ eff $\mathrm{cm}^{2} / \mathrm{s}$ & Leach index & Leach index \\
\hline 2 & $3.70 \mathrm{E}-07$ & $3.53 \mathrm{E}-07$ & 6.4 & 6.5 & $1.4 \mathrm{E}-07$ & $5.3 \mathrm{E}-08$ & 6.85 & 7.27 \\
\hline 7 & 2.69E-09 & $5.85 \mathrm{E}-09$ & 8.6 & 8.2 & $2.8 \mathrm{E}-08$ & $1.5 \mathrm{E}-08$ & 7.55 & 7.84 \\
\hline 24 & $5.14 \mathrm{E}-09$ & $1.10 \mathrm{E}-08$ & 8.3 & 8.0 & $2.1 \mathrm{E}-08$ & $1.9 \mathrm{E}-08$ & 7.67 & 7.72 \\
\hline 48 & $2.11 \mathrm{E}-09$ & $3.76 \mathrm{E}-09$ & 8.7 & 8.4 & $1.2 \mathrm{E}-08$ & $1.2 \mathrm{E}-08$ & 7.93 & 7.93 \\
\hline 72 & $7.23 \mathrm{E}-10$ & $1.04 \mathrm{E}-09$ & 9.1 & 9.0 & $8.5 \mathrm{E}-09$ & 9.2E-09 & 8.07 & 8.04 \\
\hline 96 & $2.30 \mathrm{E}-10$ & $3.07 \mathrm{E}-10$ & 9.6 & 9.5 & $6.8 \mathrm{E}-09$ & 7.6E-09 & 8.17 & 8.12 \\
\hline 120 & $8.47 \mathrm{E}-11$ & $1.32 \mathrm{E}-10$ & 10.1 & 9.9 & $6.7 \mathrm{E}-09$ & 7.8E-09 & 8.17 & 8.11 \\
\hline 456 & $2.98 \mathrm{E}-10$ & $5.40 \mathrm{E}-10$ & 9.5 & 9.3 & $3.9 \mathrm{E}-09$ & 4.7E-09 & 8.41 & 8.33 \\
\hline 1200 & $1.30 \mathrm{E}-11$ & $1.79 \mathrm{E}-11$ & 10.9 & 10.7 & $1.5 \mathrm{E}-09$ & 1.9E-09 & 8.81 & 8.71 \\
\hline \multirow[t]{3}{*}{2208} & $3.32 \mathrm{E}-12$ & $4.69 \mathrm{E}-12$ & 11.5 & 11.3 & $7.9 \mathrm{E}-10$ & $1.0 \mathrm{E}-09$ & 9.10 & 9.00 \\
\hline & & ${ }^{1} \mathrm{~L}$ bar $=$ & 9.3 & 9.1 & & ${ }^{1} \mathrm{~L}$ bar $=$ & 8.1 & 8.1 \\
\hline & \multicolumn{4}{|c|}{ " $\mathrm{Re} / \mathrm{I}$ concrete column with $12 \% \mathrm{Fe}$} & \multicolumn{4}{|c|}{ "Re/I concrete column with $12 \%$ ZVI } \\
\hline Time $\mathrm{Hr}$ & $\operatorname{Re}$ & I & $\begin{array}{l}\text { Leach } \\
\text { index }\end{array}$ & $\begin{array}{l}\text { Leach } \\
\text { index }\end{array}$ & $\operatorname{Re}$ & I & $\operatorname{Re}$ & I \\
\hline & $\mathrm{D}$ eff $\mathrm{cm}^{2} / \mathrm{s}$ & $\mathrm{D}$ eff $\mathrm{cm}^{2} / \mathrm{s}$ & $\mathrm{Re}$ & $\mathrm{I}$ & $\mathrm{D}$ eff $\mathrm{cm}^{2} / \mathrm{s}$ & $\mathrm{D}$ eff $\mathrm{cm}^{2} / \mathrm{s}$ & Leach index & Leach index \\
\hline 2 & $2.57 \mathrm{E}-07$ & $2.00 \mathrm{E}-07$ & 6.6 & 6.7 & $1.9 \mathrm{E}-07$ & $5.1 \mathrm{E}-08$ & 6.72 & 7.29 \\
\hline 7 & $1.44 \mathrm{E}-09$ & $3.28 \mathrm{E}-09$ & 8.8 & 8.5 & $4.2 \mathrm{E}-08$ & $1.7 \mathrm{E}-08$ & 7.38 & 7.77 \\
\hline 24 & $2.18 \mathrm{E}-09$ & $4.28 \mathrm{E}-09$ & 8.7 & 8.4 & $3.1 \mathrm{E}-08$ & $2.3 \mathrm{E}-08$ & 7.51 & 7.63 \\
\hline 48 & $1.67 \mathrm{E}-09$ & $2.80 \mathrm{E}-09$ & 8.8 & 8.6 & $1.8 \mathrm{E}-08$ & $1.6 \mathrm{E}-08$ & 7.75 & 7.80 \\
\hline 72 & $5.17 \mathrm{E}-10$ & $7.10 \mathrm{E}-10$ & 9.3 & 9.1 & $1.3 \mathrm{E}-08$ & $1.3 \mathrm{E}-08$ & 7.88 & 7.88 \\
\hline 96 & $1.40 \mathrm{E}-10$ & $2.07 \mathrm{E}-10$ & 9.9 & 9.7 & $1.1 \mathrm{E}-08$ & $1.1 \mathrm{E}-08$ & 7.97 & 7.95 \\
\hline 120 & $5.72 \mathrm{E}-11$ & $7.04 \mathrm{E}-11$ & 10.2 & 10.2 & $1.1 \mathrm{E}-08$ & $1.2 \mathrm{E}-08$ & 7.95 & 7.90 \\
\hline 456 & $2.24 \mathrm{E}-10$ & $2.73 \mathrm{E}-10$ & 9.7 & 9.6 & $6.9 \mathrm{E}-09$ & $8.3 \mathrm{E}-09$ & 8.16 & 8.08 \\
\hline 1200 & $1.05 \mathrm{E}-11$ & $1.46 \mathrm{E}-11$ & 11.0 & 10.8 & $3.0 \mathrm{E}-09$ & $3.7 \mathrm{E}-09$ & 8.53 & 8.44 \\
\hline 2208 & $2.29 \mathrm{E}-12$ & $2.57 \mathrm{E}-12$ & 11.6 & 11.6 & $1.5 \mathrm{E}-09$ & $1.9 \mathrm{E}-09$ & 8.82 & 8.72 \\
\hline & & ${ }^{1} \mathrm{~L}$ bar $=$ & 9.5 & 9.3 & & ${ }^{1} \mathrm{~L}$ bar $=$ & 7.9 & 7.9 \\
\hline
\end{tabular}

\footnotetext{
${ }^{1}$ Average leach index
} 
Table 5-4 presents the calculated effective diffusion coefficient for Tc and I at 4\%, $8 \%$, and $12 \%$ iron, as RNIP. The leaching indices for I were comparable to those previously quantified from waste forms containing $4 \%, 8 \%$, and $12 \%$ iron, as metallic iron ( -40 to +60 mesh) and RNIP (Table 5-3). The leaching indices indicate that in the presence of $4 \%$ and $8 \%$ zero valent iron (ZVI), Tc had higher leachability than Re. However, there was no difference in the leachability of Tc and Re when the waste form contained $12 \%$ ZVI.

Deviations in the chemical reduction of pertechnetate and perrhenate in the presence of organic ligands have been recently noted (Maset et al. 2006). Our results indicated that the presence of organic ligands did not cause a measurable difference in the solubility of Tc. Moreover, Wellman et al. (2006) noted a decrease in the diffusion of Tc versus Re from concrete waste forms. Thus, although the pertechnetate and perrhenate anions are comparable surrogates based on size, Re does not function as an analogue for Tc under redox conditions.

Table 5-4. Leach Index Data for Tc and I as a Functions of ZVI Particle Concentration

\begin{tabular}{|c|c|c|c|}
\hline \multicolumn{4}{|c|}{ "Tc/I concrete column with 4\% ZVI } \\
\hline Tc & I & Tc & I \\
\hline $\mathrm{D}$ eff $\mathrm{cm}^{2} / \mathrm{s}$ & $\mathrm{D}$ eff $\mathrm{cm}^{2} / \mathrm{s}$ & Leach index & Leach index \\
\hline $6.5 \mathrm{E}-08$ & $4.8 \mathrm{E}-08$ & 7.19 & 7.32 \\
\hline $3.4 \mathrm{E}-08$ & $2.5 \mathrm{E}-08$ & 7.47 & 7.59 \\
\hline $3.4 \mathrm{E}-08$ & $2.5 \mathrm{E}-08$ & 7.46 & 7.61 \\
\hline $3.1 \mathrm{E}-08$ & $2.0 \mathrm{E}-08$ & 7.51 & 7.71 \\
\hline $2.6 \mathrm{E}-08$ & $1.6 \mathrm{E}-08$ & 7.59 & 7.81 \\
\hline $2.1 \mathrm{E}-08$ & $1.3 \mathrm{E}-08$ & 7.67 & 7.90 \\
\hline $2.0 \mathrm{E}-08$ & $1.1 \mathrm{E}-08$ & 7.70 & 7.94 \\
\hline $9.5 \mathrm{E}-09$ & $5.4 \mathrm{E}-09$ & 8.02 & 8.27 \\
\hline $3.2 \mathrm{E}-09$ & $1.8 \mathrm{E}-09$ & 8.50 & 8.74 \\
\hline $1.5 \mathrm{E}-09$ & $8.5 \mathrm{E}-10$ & 8.83 & 9.07 \\
\hline & $\mathrm{L}$ bar $=$ & 7.8 & 8.0 \\
\hline \multicolumn{4}{|c|}{ Tc/I concrete column with $8 \%$ ZVI } \\
\hline Tc & $\mathrm{I}$ & Tc & $\mathrm{I}$ \\
\hline $\mathrm{D}$ eff $\mathrm{cm}^{2} / \mathrm{s}$ & $\mathrm{D}$ eff $\mathrm{cm}^{2} / \mathrm{s}$ & Leach index & Leach index \\
\hline $1.3 \mathrm{E}-07$ & $8.4 \mathrm{E}-08$ & 6.88 & 7.08 \\
\hline $4.2 \mathrm{E}-08$ & $2.9 \mathrm{E}-08$ & 7.37 & 7.54 \\
\hline $3.5 \mathrm{E}-08$ & $2.3 \mathrm{E}-08$ & 7.46 & 7.64 \\
\hline $3.0 \mathrm{E}-08$ & $1.8 \mathrm{E}-08$ & 7.52 & 7.73 \\
\hline $2.9 \mathrm{E}-08$ & $1.7 \mathrm{E}-08$ & 7.54 & 7.77 \\
\hline $2.6 \mathrm{E}-08$ & $1.5 \mathrm{E}-08$ & 7.58 & 7.82 \\
\hline $2.8 \mathrm{E}-08$ & $1.6 \mathrm{E}-08$ & 7.55 & 7.79 \\
\hline $1.3 \mathrm{E}-08$ & $8.7 \mathrm{E}-09$ & 7.89 & 8.06 \\
\hline $4.3 \mathrm{E}-09$ & $3.0 \mathrm{E}-09$ & 8.36 & 8.53 \\
\hline \multirow[t]{2}{*}{$2.0 \mathrm{E}-09$} & $1.4 \mathrm{E}-09$ & 8.69 & 8.85 \\
\hline & $\mathrm{L}$ bar $=$ & 7.7 & 7.9 \\
\hline
\end{tabular}


Table 5.4. (continued)

\begin{tabular}{|c|c|c|c|}
\hline \multicolumn{4}{|c|}{ 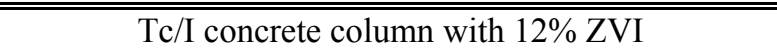 } \\
\hline Tc & $\mathrm{I}$ & Tc & I \\
\hline $\mathrm{D}$ eff $\mathrm{cm}^{2} / \mathrm{s}$ & $\mathrm{D}$ eff $\mathrm{cm}^{2} / \mathrm{s}$ & Leach index & Leach index \\
\hline$\overline{7.0 \mathrm{E}-08}$ & 5.2E-08 & $\overline{77.15}$ & 7.29 \\
\hline $2.6 \mathrm{E}-08$ & $2.1 \mathrm{E}-08$ & 7.59 & 7.69 \\
\hline $2.2 \mathrm{E}-08$ & $1.6 \mathrm{E}-08$ & 7.66 & 7.79 \\
\hline $2.1 \mathrm{E}-08$ & $1.4 \mathrm{E}-08$ & 7.68 & 7.85 \\
\hline $2.1 \mathrm{E}-08$ & $1.3 \mathrm{E}-08$ & 7.69 & 7.88 \\
\hline $1.9 \mathrm{E}-08$ & $1.2 \mathrm{E}-08$ & 7.72 & 7.92 \\
\hline $2.0 \mathrm{E}-08$ & $1.3 \mathrm{E}-08$ & 7.69 & 7.88 \\
\hline $9.1 \mathrm{E}-09$ & $7.0 \mathrm{E}-09$ & 8.04 & 8.15 \\
\hline $3.0 \mathrm{E}-09$ & $2.4 \mathrm{E}-09$ & 8.52 & 8.61 \\
\hline $1.4 \mathrm{E}-09$ & $1.2 \mathrm{E}-09$ & 8.85 & 8.94 \\
\hline & L bar $=$ & 7.9 & 8.0 \\
\hline
\end{tabular}




\subsection{Reactivity of Limited Solubility U(VI) bearing Compounds in Concrete}

During FY2004, Portland cement grout specimens were prepared with a U(VI) nitrate spike. The specimens were aged for various time spans ranging from 2 weeks to 1 year. A scanning electron microscopy/energy dispersive spectrometer was used to identify the uranium-bearing compounds that formed in the specimens. The uranium phases were identified to be that of soddyite, becquerelite, uranophane, and autunite. A literature search conducted in FY2004 revealed that reliable thermochemical data are not available for these phases under conditions present in concrete waste forms. In FY2006, we developed synthetic routes for the precipitation of pure uranium phases. In FY2007, we have measured the solubility data for these uranium-solid phases by conducting equilibrium solubility measurements under concrete porewater conditions. These data are expected to lead to better performance assessment modeling of uranium releases from waste-form concrete.

\subsection{Synthesis of U(VI) Phases}

All solutions were prepared with reagent-grade chemicals and $18 \mathrm{M} \Omega$ deionized water.

\subsubsection{Soddyite Precipitation}

Direct precipitation of soddyite was conducted based on modified procedures presented by (Nguyen et al. 1992; Casas et al. 1997). Deionized water $(50 \mathrm{~mL})$ was boiled for 30 minutes while sparging with nitrogen to remove all carbon dioxide. A $0.15 \mathrm{M}$ uranyl nitrate, $\mathrm{UO}_{2}\left(\mathrm{NO}_{3}\right)_{2} \cdot 6 \mathrm{H}_{2} \mathrm{O}$ (Alfa Aesar) solution was prepared by adding $3.138 \mathrm{~g}$ uranyl nitrate to $40 \mathrm{~mL}$ of de-air water, which was boiled and sparged with nitrogen,. Sodium metasilicate $\left(1.77 \mathrm{~g}\right.$ ), $\mathrm{NaSiO}_{3} \cdot 9 \mathrm{H}_{2} \mathrm{O}$ (Alfa Aesar), was added to $10 \mathrm{~mL}$ of deaired water, which was boiled and sparged with nitrogen, to prepare a $0.30 \mathrm{M}$ solution. The sodium metasilicate solution was added drop-wise, with stirring, to the $0.15 \mathrm{M}$ uranyl nitrate solution under anaerobic conditions. Concentrated ammonium hydroxide solution was added drop-wise with stirring until the $\mathrm{pH}$ was within a range of 4.5 to 5.0. The solution was allowed to stir under anaerobic conditions for 100 hours. The crystals were washed with boiling deionized water. The solid phase was placed into a Parr reactor with $75 \mathrm{~mL}$ of boiling deionized water. The reactor was sealed and heated for 14 days at $130^{\circ} \mathrm{C}$. The resulting crystals were washed with boiling deionized water, recovered from solution through centrifugation, and dried at room temperature until a constant weight was achieved.

\subsubsection{Becquerelite Precipitation}

Direct precipitation of becquerelite was accomplished using methods of Burns et al. (personal communication). Uranyl acetate $(0.313 \mathrm{~g})\left[\mathrm{UO}_{2}\left(\mathrm{CH}_{3} \mathrm{COO}\right)_{2} \bullet 2 \mathrm{H}_{2} \mathrm{O}\right]$ was combined with $0.05 \mathrm{~g}$ calcium carbonate $\left(\mathrm{CaCO}_{3}\right)$ in $4 \mathrm{~mL}$ deionized water. The solution was placed in a Parr bomb and heated at $160^{\circ} \mathrm{C}$ for 50 hours. The light-mustard-colored precipitate was recovered from solution through centrifugation. The crystals were washed with four aliquots of boiling deionized water. The crystals were dried at room temperature until a constant weight was achieved. 


\subsubsection{Uranophane Precipitation}

Direct precipitation of uranophane was accomplished using methods of Burns et al. (personal communication). Uranyl acetate $(0.42 \mathrm{~g})\left[\mathrm{UO}_{2}\left(\mathrm{CH}_{3} \mathrm{COO}\right)_{2} \bullet 2 \mathrm{H}_{2} \mathrm{O}\right]$ was combined with $0.23 \mathrm{~g}$ sodium metasilicate $\left[\mathrm{NaSiO}_{3} \bullet 9 \mathrm{H}_{2} \mathrm{O}\right]$ and $0.28 \mathrm{~g}$ calcium acetate $\left[\mathrm{Ca}\left(\mathrm{CH}_{2} \mathrm{OOH}\right)_{2} \bullet \mathrm{H}_{2} \mathrm{O}\right]$ in $5 \mathrm{~mL}$ deionized water. The $\mathrm{pH}$ of the solution was adjusted to $5.5 \mathrm{using}$ glacial acetic acid $\left[\mathrm{CH}_{3} \mathrm{COOH}\right]$. The solution was placed in a Parr bomb and heated at $100^{\circ} \mathrm{C}$ for 24 hours. The pale yellow precipitate was recovered from solution through centrifugation. The crystals were washed with four aliquots of boiling deionized water. The crystals were dried at room temperature until a constant weight was achieved.

\subsection{Characterization of U(VI) Phases}

\subsubsection{X-ray Diffraction}

$\mathrm{X}$-ray diffraction is a commonly used technique for identifying crystalline minerals that are $\geq 5 \%$ (by weight) of the bulk composition. Before mounting, a representative sample of the bulk material was ground using an agate mortar and pestle to improve the diffraction patterns. X-ray diffraction data were obtained at $45 \mathrm{kV}$ and $40 \mathrm{~mA}$, using a Scintag ${ }^{\circledR}$ automated powder diffractometer (Model 3520).

Tungsten-filtered copper radiation, $\mathrm{CuK}_{\alpha}=1.54 \AA$, was used to obtain diffraction patterns. The samples were analyzed over the 2-theta $(2 \theta)$ range from $2^{\circ}$ to $45^{\circ}$, using a step size of $0.04^{\circ}$, and a 2 - second count time at each step.

\subsection{Solubility of U(VI) Phases}

The solubility of soddyite, becquerelite, and uranophane was measured under concrete porewater conditions. Ewart et al. (1992) measured the elemental compositions of porewaters equilibrated with a series of Portland cement compositions: sulfate-resistant Portland cement (SRPC)/limestone (L), ordinary Portland cement (OPC)/blast furnace slag (BFS)/L, BFS/OPC, OPC/L, and Harwell. Based on these data, a series of synthetic cement leachates were prepared with $18 \mathrm{M} \Omega$ deionized water and reagent-grade chemicals from Aldrich Chemicals, namely calcium chloride $\left[\mathrm{CaCl}_{2} \cdot 2 \mathrm{H}_{2} \mathrm{O}\right]$, magnesium chloride $\left[\mathrm{MgCl}_{2}\right.$ $\left.6 \mathrm{H}_{2} \mathrm{O}\right]$, calcium sulfate $\left[\mathrm{CaSO}_{4}\right]$, sodium hydroxide $[\mathrm{NaOH}]$, calcium carbonate $\left[\mathrm{CaCO}_{3}\right]$, calcium hydroxide $\left[\mathrm{Ca}(\mathrm{OH})_{2}\right]$, silicic acid $\left[\mathrm{SiO}_{2} \bullet 2 \mathrm{H}_{2} \mathrm{O}\right]$, and aluminum nitrate $\left[\mathrm{Al}\left(\mathrm{NO}_{3}\right)_{3} \cdot 9 \mathrm{H}_{2} \mathrm{O}\right]($ Table 6-1).

Table 6-1. Chemical Composition of Portland Cement-Equilibrated Waters

\begin{tabular}{|c|c|c|c|c|c|c|c|c|c|}
\hline \multicolumn{10}{|c|}{ Concentration, $\mathrm{M}$} \\
\hline Cement & $\mathrm{Ca}$ & $\mathrm{Na}$ & $\mathrm{Mg}$ & $\mathrm{Cl}$ & $\mathrm{SO}_{4}{ }^{2-}$ & $\mathrm{CO}_{3}{ }^{2-}$ & $\mathrm{Al}$ & $\mathrm{Si}$ & $\mathrm{pH}$ \\
\hline SRPC/L & $6.7 \mathrm{E}-3$ & $2 \mathrm{E}-4$ & $<8 \mathrm{E}-8$ & $4 \mathrm{E}-5$ & $4 \mathrm{E}-5$ & $8.5 \mathrm{E}-5$ & $7.4 \mathrm{E}-4$ & $5.3 \mathrm{E}-6$ & 12.5 \\
\hline 9:1 BFS/OPC & $6.8 \mathrm{E}-3$ & $3.4 \mathrm{E}-3$ & $4.7 \mathrm{E}-7$ & $6.2 \mathrm{E}-5$ & & $1 \mathrm{E}-4$ & $8 \mathrm{E}-5$ & $2.3 \mathrm{E}-5$ & 12.2 \\
\hline $\mathrm{OPC} / \mathrm{BFS} / \mathrm{L}$ & $6.7 \mathrm{E}-3$ & $5 \mathrm{E}-3$ & $<8 \mathrm{E}-7$ & $2.4 \mathrm{E}-3$ & $6 \mathrm{E}-3$ & $2.8 \mathrm{E}-4$ & $9.5 \mathrm{E}-5$ & $7 \mathrm{E}-4$ & 12.1 \\
\hline $\mathrm{OPC} / \mathrm{L}$ & $2 \mathrm{E}-2$ & $8.3 \mathrm{E}-4$ & $<4 \mathrm{E}-8$ & $9 \mathrm{E}-5$ & $1 \mathrm{E}-5$ & $2 \mathrm{E}-5$ & $1 \mathrm{E}-5$ & & 12 \\
\hline HARWELL & $1 \mathrm{E}-2$ & $5 \mathrm{E}-5$ & $5 \mathrm{E}-6$ & $2 \mathrm{E}-3$ & $3 \mathrm{E}-3$ & $3 \mathrm{E}-5$ & & & 12 \\
\hline
\end{tabular}

(Ewart et al. 1992) 
A series of synthetic porewaters were prepared based on these compositions. The solubility of soddyite, becquerelite, and uranophane in the synthetic porewater solutions were measured over a period of 3 months. Approximately $0.1 \mathrm{~g}$ of the respective uranium phase was added to polypropylene tubes containing $20 \mathrm{~mL}$ of the respective porewater solution. The tubes were sealed and shaken for predetermined sample intervals of $1,2,7,14,28,32,64$, and 128 days. The suspensions were centrifuged and the supernatant was filtered through $0.45 \mu \mathrm{m}$ filters. The filtrate was acidified with nitric acid and analyzed via ICP-OES for silicon and calcium and ICP-MS for uranium.

\subsection{Results and Discussion}

\subsubsection{Characterization of U(VI) Phases}

Figure 6.1 displays X-ray diffraction patterns for synthetic soddyite, becquerelite, and uranophane. $\mathrm{X}$-ray diffraction patterns for soddyite, becquerelite, and uranophane are consisted with published spectra.

\subsubsection{Solubility of U(VI) Phases}

Results of solubility experiments are pending, due to analytical delays, and will be presented in a FY08 mid-year report. 

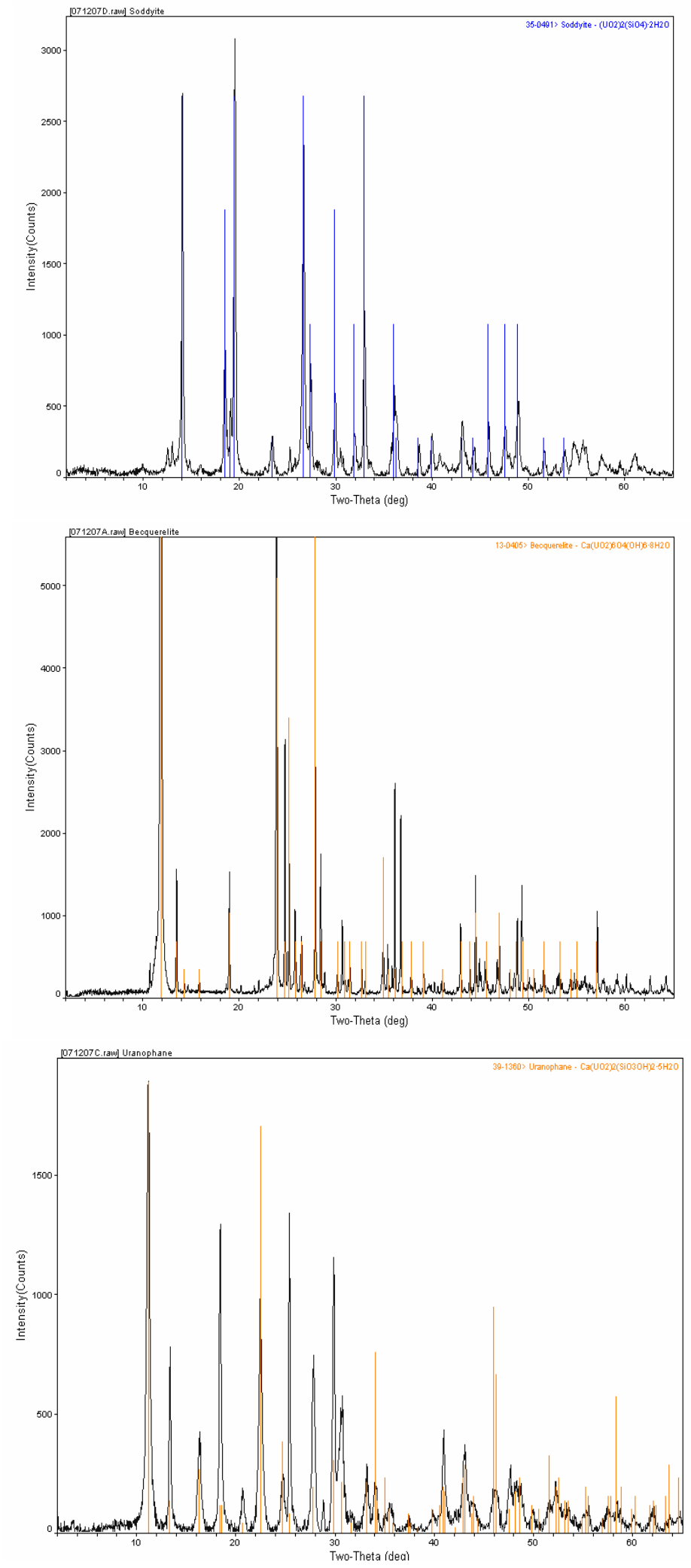

Figure 6.1. X-ray Diffraction Pattern for Soddyite (top), Becquerelite (middle), and Uranophane (bottom) 


\subsection{References}

American National Standards Institute. 2004. Measurement of the Leachability of Solidified Low-Level Radioactive Wastes by a Short-Term Test Procedure, ANS/ANSI-16.1-2003.

Casas I, I Perez, ME Torrero, J Bruno, E Cera, and L Duro. 1997. Dissoulution Studies of Synthetic Soddyite and Uranophane, 97-15,

Ewart FT, JL Smith-Briggs, HP Thonason, and SJ Williams. 1992. "The Solubility of Actinides in a Cementitious near-Field Environment." Waste Management 12:241-252.

Mann FM, RJ Puigh II, SH Finfrock, EJ Freeman, R Khaleel, DH Bacon, MP Bergeron, PB McGrail, and SK Wurstner. 2001. Hanford Immobilized Low-Activity Waste Performance Assessment: 2001 Version, DOE/ORP-2000-24, Rev. B. Pacific Northwest National Laboratory, Richland, WA.

Maset ER, SH Sidhu, A Fisher, A Heydon, PJ Worsfold, AJ Cartwright, and MJ Keith-Roach. 2006. "Effect of Organic Co-Contaminants on Technetium and Rhenium Speciation and Solubility under Reducing Conditions." Environmental Science and Technology 40(17):5472-5477.

Mattigod SV, GA Whyatt, RJ Serne, PF Martin, KE Schwab, and MI Wood. 2001. Diffusion and Leaching of Selected Radionuclides (Iodine-129, Technetium-99, and Uranium) through Category 3 Waste Encasement Concrete and Soil Fill Material, PNNL-13639. Pacific Northwest National Laboratory, Richland, WA.

Nguyen SN, RJ Silva, HC Weed, and JE Andrews. 1992. "Standard Gibbs Free Energies of Formation at the Temperature 303.15k of Four Uranyl Silicates: Soddyite, Uranophane, Sodium Boltwoodite, and Sodium Weeksite." Journal of Chemical Thermodynamics 25:359-376.

Serne RJ, JL Conca, VL LeGore, KJ Cantrell, CW Lindenmeier, JA Campbell, JE Amonette, and MI Wood. 1993. Solid-Waste Leach Characterization and Contaminant-Sediment Interactions, PNL-8889, Vol. 1. Pacific Northwest Laboratory, Richland, WA.

Serne RJ, RO Lokken, and LJ Criscenti. 1992. "Characterization of Grouted LLW to Support Performance Assessment." Waste Management 12:271-287.

Serne RJ, WJ Martin, and VL LeGore. 1995. Leach Test of Cladding Removal Waste Grout Using Hanford Groundwater, PNL-10745. Pacific Northwest Laboratory, Richland, WA.

Serne RJ, WJ Martin, VL LeGore, CW Lindenmeier, SB McLaurine, PFC Martin, and RO Lokken. 1989. Leach Tests on Grouts Made with Actual and Trace Metal-Spiked Synthetic Phosphate/Sulfate Waste., PNL-7121. Pacific Northwest Laboratory, Richland, WA.

Wellman DM, SV Mattigod, GA Whyatt, L Powers, KE Parker, LN Clayton, and MI Wood. 2006. Diffusion of Iodine and Rhenium in Category 3 Waste Encasement Concrete and Soil Fill Material, PNNL-16268. Pacific Northwest National Laboratory, Richland, WA. 
Wood MI, R Khaleel, PD Rittman, AH Lu, S Finfrock, RJ Serne, and KJ Cantrell. 1995. Performance Assessment for the Disposal of Low-Level Waste in the 218-W-5 Burial Ground, WHC-EP-0645. Westinghouse Hanford Company, Richland, WA. 